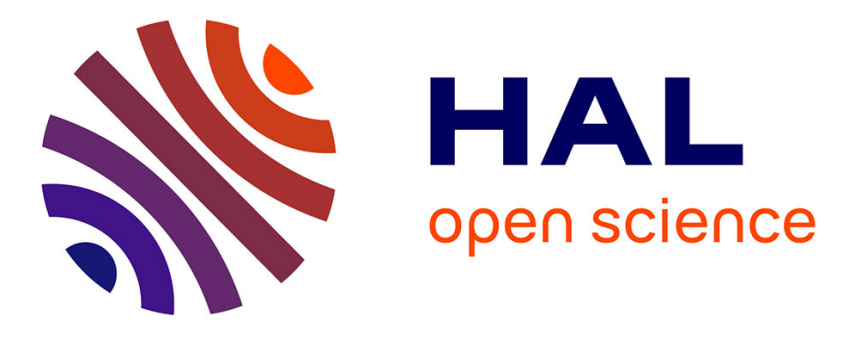

\title{
Exploration of the antibiotic potentiating activity of indolglyoxylpolyamines
}

\author{
Melissa M Cadelis, Elliot I W Pike, Weirong Kang, Zimei Wu, Marie-Lise \\ Bourguet-Kondracki, Marine Blanchet, Nicolas Vidal, Jean Michel Brunel, \\ Brent R Copp
}

\section{To cite this version:}

Melissa M Cadelis, Elliot I W Pike, Weirong Kang, Zimei Wu, Marie-Lise Bourguet-Kondracki, et al.. Exploration of the antibiotic potentiating activity of indolglyoxylpolyamines. European Journal of Medicinal Chemistry, 2019, 183, pp.111708. 10.1016/j.ejmech.2019.111708 . hal-03020885

\section{HAL Id: hal-03020885 \\ https://cnrs.hal.science/hal-03020885}

Submitted on 24 Nov 2020

HAL is a multi-disciplinary open access archive for the deposit and dissemination of scientific research documents, whether they are published or not. The documents may come from teaching and research institutions in France or abroad, or from public or private research centers.
L'archive ouverte pluridisciplinaire HAL, est destinée au dépôt et à la diffusion de documents scientifiques de niveau recherche, publiés ou non, émanant des établissements d'enseignement et de recherche français ou étrangers, des laboratoires publics ou privés. 


\section{Exploration of the antibiotic potentiating activity of indolglyoxylpolyamines}

Melissa M. Cadelis a , Elliot I. W. Pike a , Weirong Kang ${ }^{\text {b,c }}$, Zimei Wu ${ }^{\text {b }}$, Marie-Lise Bourguet-Kondracki ${ }^{\text {d }}$, Marine Blanchet ${ }^{\mathrm{e}}$, Nicolas Vidal ${ }^{\mathrm{f}}$, Jean Michel Brunel ${ }^{\mathrm{e}}$, and Brent R. Copp ${ }^{\mathrm{a}, *}$

${ }^{a}$ School of Chemical Sciences, The University of Auckland, Private Bag 92019, Auckland 1142, New Zealand

${ }^{b}$ School of Pharmacy, The University of Auckland, Private Bag 92019, Auckland 1142, New Zealand

${ }^{c}$ Current address: School of Chinese Medicine, Hong Kong Baptist University, Kowloon 999077, Hong Kong

${ }^{d}$ Laboratoire Molécules de Communication et Adaptation des Micro-organismes, UMR 7245 CNRS, Muséum National d'Histoire Naturelle, 57 rue Cuvier (C.P. 54), 75005 Paris, France

e Aix Marseille Univ, INSERM, SSA, MCT, Faculté de pharmacie, 27 bd Jean Moulin, 13385 Marseille, France

${ }^{f}$ YELEN, 10 bd tempête, 13820 Ensues la redonne, France

*Corresponding author. Brent R. Copp (b.copp@auckland.ac.nz)

\section{Keywords}

Polyamine; indole; indolglyoxylamide; potentiation; antimicrobial 


\begin{abstract}
A series of substituted di-indolglyoxylamido-spermine analogues were prepared and evaluated for intrinsic antimicrobial properties and the ability to enhance antibiotic action. As a compound class, intrinsic activity was typically observed towards Gram-positive bacteria and the fungus Cryptococcus neoformans, with notable exceptions being the 5-bromo- and 6-chloro-indole analogues which also exhibited modest activity (MIC 34$50 \mu \mathrm{M}$ ) towards the Gram-negative bacteria Escherichia coli and Klebsiella pneumoniae. Several analogues enhanced the activity of doxycycline towards the Gram-negative bacteria Pseudomonas aeruginosa, E. coli, K. pneumoniae and Acinetobacter baumannii. Of particular note was the identification of five antibiotic enhancing analogues (5-Br, 7-F, 5-Me, 7-Me, 7-OMe) which also exhibited low to no cytotoxicity and red blood cell haemolytic properties. The mechanisms of action of the 5-Br and 7-F analogues were attributed to the ability to disrupt the integrity of, and depolarize, bacterial membranes.
\end{abstract}




\section{Introduction}

Given the noted difficulties associated with the discovery and development of novel antibiotics [1][2][3], and particularly those with activity towards Gram-negative bacteria [4][5], an attractive approach for overcoming antimicrobial resistance is the identification of antibiotic adjuvants [6][7][8]. Such compounds, when co-dosed with antibiotics, have the potential to restore the action of an antibiotic towards bacteria that have developed resistance to that antibiotic. Beyond the classical adjuvant example, the $\beta$-lactamase inhibitor clavulanic acid co-dosed with the $\beta$-lactam antibiotic amoxicillin, a growing number of chemical scaffolds have been identified as being able to enhance antibiotic action [9][10]. Two such examples include the marine natural product ianthelliformisamine $\mathrm{C} \mathbf{1}$ and 2-aminoimidazole analogues such as $\mathbf{2}$ (Fig. 1) the former which acts via bacterial membrane depolarization [11] while the latter compound class causes potentiation by disruption of the VraSR two-component system associated with cell wall biosynthesis [12].<smiles>CCCCCc1ccc(C(=O)NCCn2cc(CCCCCc3cnc(N)n3Cc3ccc(CCCC)cc3)nn2)cc1</smiles><smiles>O=C(NCCCNCCCCNCCCNC(=O)c1c[nH]c2cc(Br)ccc12)C(=O)c1c[nH]c2cc(Br)ccc12</smiles>

Fig. 1. Structures of antibiotic potentiators 1-3.

We recently reported polyamine functionalised indolglyoxylamide 3 (Fig. 1) as a potentiator of antibiotic activity towards several examples of clinically important Gram-negative bacteria including Pseudomonas aeruginosa [13]. That same study provided insight into some of the structural elements required for potentiation, namely an intact polyamine core of suitable overall length. The biological activities of $\mathbf{3}$, which also included intrinsic antibacterial activity towards Gram-positive bacteria and fungi, were attributed to the molecules ability to disrupt the integrity of, and depolarize, bacterial membranes. This ability to disrupt membranes also extended to mammalian cells, with $\mathbf{3}$ exhibiting cytotoxicity and also strong red blood cell haemolytic activities. We used $\mathbf{3}$ as a starting point for a new study, reported herein, that explored the effect 
of variation of substitution on the indolglyoxylamide fragment in search for new potentiators that were devoid of cytotoxic/haemolytic liabilities.

\section{Chemistry}

A library of analogues of were prepared, exploring the influence of the 6-bromo substituent present in 3. The method used for the synthesis of target compounds 4-19, summarised in Scheme 1, was comprised of a three-step sequence starting with conversion of commercially available or previously reported substituted indoles to their corresponding 3-glyoxylchloride analogue. Subsequent reaction with the Boc-protected PA34-3 di-tert-butyl butane-1,4-diylbis((3-aminopropyl)carboxylate) afforded Boc protected intermediates that were then directly subjected to Boc group deprotection (with TFA in $\mathrm{CH}_{2} \mathrm{Cl}_{2}$ or $\mathrm{MeOH}$ ) to give tetramine diamides 4-19 as their di-TFA salts. Preparation of the 4-fluoroindole analogue by this glyoxylchloride method gave the desired product (20) in very low $(<10 \%)$ yield - an alternative preparation via reaction of 2-(4-fluoro1H-indol-3-yl)-2-oxoacetic acid [14] with spermine mediated by the coupling agent PyBOP in DMF afforded 20 in a marginally better yield of 14\% (Scheme 2). The set of analogues was rounded off with des-bromo 21 and three methoxy derivatives (22-24) previously reported by us (Fig. 2) [15]. 
<smiles>[R]c1cc2cc[nH]c2c([R3])c1[R]</smiles><smiles>[R]c1cc2c(C(=O)C(=O)NCCC[NH2+]CCC([Y2])(C)C)c[nH]c2c([R3])c1[R]</smiles>

$4 \mathrm{R}_{2}=\mathrm{R}_{3}=\mathrm{H}, \mathrm{R}_{1}=\mathrm{Br}$

$5 \mathrm{R}_{3}=\mathrm{H}, \mathrm{R}_{1}=\mathrm{R}_{2}=\mathrm{Br}$

$6 R_{2}=R_{3}=H, R_{1}=F$

$7 \mathrm{R}_{1}=\mathrm{R}_{3}=\mathrm{H}, \mathrm{R}_{2}=\mathrm{F}$

$8 R_{1}=R_{2}=H, R_{3}=F$

$9 \mathrm{R}_{2}=\mathrm{R}_{3}=\mathrm{H}, \mathrm{R}_{1}=\mathrm{Cl}$

$10 \mathrm{R}_{1}=\mathrm{R}_{3}=\mathrm{H}, \mathrm{R}_{2}=\mathrm{Cl}$

$11 \mathrm{R}_{1}=\mathrm{R}_{2}=\mathrm{H}, \mathrm{R}_{3}=\mathrm{Cl}$

$12 \mathrm{R}_{1}=\mathrm{R}_{3}=\mathrm{H}, \mathrm{R}_{2}=\mathrm{CF}_{3}$

$13 \mathrm{R}_{2}=\mathrm{R}_{3}=\mathrm{H}, \mathrm{R}_{1}=\mathrm{CN}$

$14 \mathrm{R}_{1}=\mathrm{R}_{3}=\mathrm{H}, \mathrm{R}_{2}=\mathrm{CN}$

$15 \mathrm{R}_{2}=\mathrm{R}_{3}=\mathrm{H}, \mathrm{R}_{1}=\mathrm{COOCH}_{3}$

$16 \mathrm{R}_{1}=\mathrm{R}_{3}=\mathrm{H}, \mathrm{R}_{2}=\mathrm{COOCH}_{3}$

$17 \mathrm{R}_{1}=\mathrm{R}_{2}=\mathrm{H}, \mathrm{R}_{3}=\mathrm{COOCH}_{3}$

$18 \mathrm{R}_{2}=\mathrm{R}_{3}=\mathrm{H}, \mathrm{R}_{1}=\mathrm{CH}_{3}$

$19 \mathrm{R}_{1}=\mathrm{R}_{2}=\mathrm{H}, \mathrm{R}_{3}=\mathrm{CH}_{3}$

Scheme 1. General synthesis of indolglyoxylamide analogues 4-19. Reagents and conditions: a) Oxalyl chloride (2 eq.), $\mathrm{Et}_{2} \mathrm{O}, 0{ }^{\circ} \mathrm{C}, 3 \mathrm{~h}$; b) Di-tert-butyl butane-1,4-diylbis((3-aminopropyl)carbamate) (0.5 eq.), DIPEA (3 eq.), DMF, r.t., 48 h; c) TFA (0.2 mL), $\mathrm{CH}_{2} \mathrm{Cl}_{2} / \mathrm{MeOH}(2 \mathrm{~mL})$, r.t., 3 h.<smiles>Cc1c[nH]c2cccc(F)c12</smiles><smiles>CC(C)(C)CCNCCCNC(=O)C(=O)c1c[nH]c2cccc(F)c12</smiles>

20

Scheme 2. Synthesis of 4-fluoroindolglyoxylamide analogue 20. Reagents and conditions: a) PyBOP (1 eq.), triethylamine (2.5 eq.), DMF, $\mathrm{N}_{2}$, r.t., 48 h. 


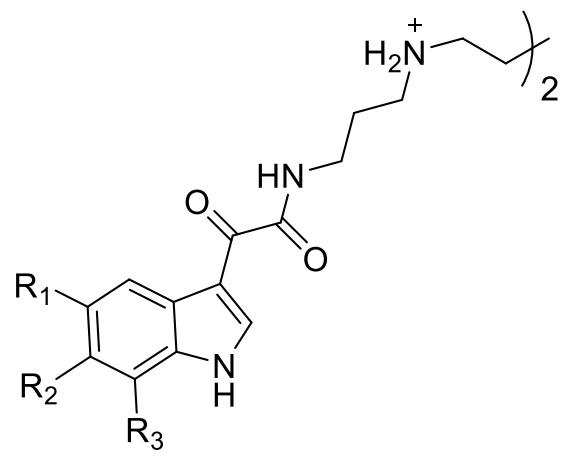

$21 R_{1}=R_{2}=R_{3}=H$

$22 \mathrm{R}_{1}=\mathrm{R}_{3}=\mathrm{H}, \mathrm{R}_{2}=\mathrm{Br}$

$23 \mathrm{R}_{1}=\mathrm{R}_{3}=\mathrm{H}, \mathrm{R}_{2}=\mathrm{OMe}$

$24 \mathrm{R}_{1}=\mathrm{R}_{2}=\mathrm{H}, \mathrm{R}_{3}=\mathrm{OMe}$

Fig. 2. Des-bromo (21) and methoxy analogues 22-24 [15]

\section{Results and discussion}

We first evaluated the intrinsic antimicrobial activity of each compound against a range of Grampositive (Staphylococcus aureus and Staphylococcus intermedius) and Gram-negative (Pseudomonas aeruginosa, Escherichia coli, Klebsiella pneumoniae and Acinetobacter baumannii) bacteria and two fungal strains (Candida albicans and Cryptococcus neoformans) (Table 1). As with the original 6-bromoindole hit compound 3, a number of the indolglyoxylamide analogues demonstrated some level of antimicrobial activity against Gram-positive bacteria and the fungus Cryptococcus neoformans. Notably analogues 4 (5-Br) and 10 (6-Cl) were the most potent, exhibiting broad spectrum antimicrobial activity against S. aureus (MIC 3.125$6.25 \mu \mathrm{M})$, S. intermedius (MIC $3.125 \mu \mathrm{M}$ ), E. coli (MIC 25-50 $\mu \mathrm{M}$ ), K. pneumoniae (MIC 34.4-38.1 $\mu \mathrm{M}$ ) and C. neoformans (MIC 2.2-4.8 $\mu \mathrm{M}$ ). The results indicated that $C$. neoformans was the most susceptible test organism, with ten analogues exhibiting MIC $<10 \mu \mathrm{M}$, while the compound class was only poorly active or inactive towards Gram-negative bacteria. 
Table 1

Antimicrobial and antifungal activities of analogues 3-24.

\begin{tabular}{|c|c|c|c|c|c|c|c|c|}
\hline & \multicolumn{8}{|c|}{$\mathrm{MIC}(\mu \mathrm{M})$} \\
\hline & S. $a^{a}$ & $S . i^{b}$ & $P . a^{c}$ & $E . c^{d}$ & $K \cdot p^{e}$ & $A . b^{f}$ & C. $a^{g}$ & C. $n^{h}$ \\
\hline 3 & $6.25^{i}$ & $3.125^{i}$ & $100^{i}$ & $100^{i}$ & $>34^{i}$ & $>34^{i}$ & $17.2^{i}$ & $1.1^{i}$ \\
\hline 4 & 3.125 & 3.125 & 50 & 25 & 34.4 & $>34.4$ & $>34.4$ & 2.2 \\
\hline 5 & 25 & n.t. $^{j}$ & 100 & 50 & $>29.4$ & $>29.4$ & $>29.4$ & 3.65 \\
\hline 6 & 25 & 50 & 200 & 200 & $>39.6$ & $>39.6$ & $>39.6$ & 9.9 \\
\hline 7 & 100 & $>200$ & $>200$ & $>200$ & $>39.6$ & $>39.6$ & $>39.6$ & 19.8 \\
\hline 8 & 25 & $>200$ & 200 & 200 & $>39.6$ & $>39.6$ & $>39.6$ & 4.9 \\
\hline 9 & $>200$ & n.t. & $>100$ & $>200$ & $>38.0$ & $>38.0$ & 38.0 & $>38.0$ \\
\hline 10 & 6.25 & 3.125 & 100 & 50 & 38.1 & 38.1 & 38.1 & 4.8 \\
\hline 11 & 50 & n.t. & 200 & 200 & $>38.1$ & $>38.1$ & $>38.1$ & 19.1 \\
\hline 12 & 50 & 50 & 200 & 100 & 35.2 & $>35.2$ & 35.2 & 4.40 \\
\hline 13 & 100 & $>200$ & $>200$ & $>200$ & $>38.9$ & $>38.9$ & $>38.9$ & 38.9 \\
\hline 14 & 100 & 25 & $>200$ & 200 & $>38.9$ & $>38.9$ & $>38.9$ & 38.9 \\
\hline 15 & 100 & 6.25 & 200 & 200 & $>36.0$ & $>36.0$ & $>36.0$ & $>36.0$ \\
\hline 16 & $>200$ & 12.5 & $>200$ & $>200$ & $>36.0$ & $>36.0$ & $>36.0$ & 9.0 \\
\hline 17 & 25 & $>200$ & 200 & 200 & $>36.0$ & $>36.0$ & $>36.0$ & 9.0 \\
\hline 18 & 25 & $>200$ & 100 & 200 & $>40.0$ & $>40.0$ & $>40.0$ & 10.0 \\
\hline 19 & 25 & 12.5 & $>200$ & $>200$ & $>40.0$ & $>40.0$ & $>40.0$ & 10.0 \\
\hline 20 & $>70$ & 35 & 140 & 100 & $>55.1$ & $>55.1$ & $>55.1$ & $>55.1$ \\
\hline 21 & $>100$ & $>100$ & $>100$ & $>100$ & $>41.4$ & $>41.4$ & $>41.4$ & 10.3 \\
\hline 22 & 100 & 50 & $>200$ & $>200$ & $>38.4$ & $>38.4$ & $>38.4$ & 19.2 \\
\hline 23 & $>100$ & $>100$ & $>100$ & $>100$ & $>38.4$ & $>38.4$ & $>38.4$ & 19.2 \\
\hline 24 & 15 & n.t. & $>200$ & $>200$ & $>38.4$ & $>38.4$ & 38.4 & $>38.4$ \\
\hline
\end{tabular}

${ }^{a}$ Staphylococcus aureus ATCC25923 with streptomycin (MIC $21.5 \mu \mathrm{M}$ ) and chloramphenicol (MIC 1.5-3 $\mu \mathrm{M})$ used as positive controls and values presented as the mean $(\mathrm{n}=3)$.

${ }^{\mathrm{b}}$ Staphylococcus intermedius 1051997 with streptomycin (MIC $10.7 \mu \mathrm{M}$ ) and chloramphenicol (MIC 3-6 $\mu \mathrm{M}$ ) used as positive controls and values presented as the mean $(\mathrm{n}=3)$.

${ }^{\mathrm{c}}$ Pseudomonas aeruginosa ATCC27853 with streptomycin (MIC $21.5 \mu \mathrm{M}$ ) and colistin (MIC $1 \mu \mathrm{M}$ ) used as positive controls and values presented as the mean $(\mathrm{n}=3)$.

${ }^{\mathrm{d}}$ Escherichia coli ATCC25922 with streptomycin (MIC $21.5 \mu \mathrm{M}$ ) and colistin (MIC $2 \mu \mathrm{M}$ ) used as positive controls and values presented as the mean $(\mathrm{n}=3)$.

${ }^{\mathrm{e}}$ Klebsiella pneumoniae ATCC700603 with colistin (MIC $0.25 \mu \mathrm{g} / \mathrm{mL}$ ) as a positive control and values presented as the mean $(\mathrm{n}=2)$.

${ }_{\mathrm{f}}^{\mathrm{f}}$ Acinetobacter baumannii ATCC19606 with colistin (MIC $0.25 \mu \mathrm{g} / \mathrm{mL}$ ) as a positive control and values presented as the mean $(\mathrm{n}=2)$.

g Candida albicans ATCC90028 with fluconazole (MIC $0.125 \mu \mathrm{g} / \mathrm{mL}$ ) as a positive control and values presented as the mean $(\mathrm{n}=2)$.

${ }^{\mathrm{h}}$ Cryptococcus neoformans ATCC208821 with fluconazole (MIC $8 \mu \mathrm{g} / \mathrm{mL}$ ) as a positive control and values presented as the mean $(\mathrm{n}=2)$.

${ }^{\mathrm{i}}$ Data taken from Li et al. [13].

${ }^{j}$ Not tested. 
The ability of compounds 3-24 to enhance the antibiotic activity of doxycycline against $P$. aeruginosa ATCC27853 was determined. These tests used a fixed concentration of doxycycline of $2 \mu \mathrm{g} / \mathrm{mL}(4.5 \mu \mathrm{M})$, which is twenty-fold lower than the intrinsic MIC $[40 \mu \mathrm{g} / \mathrm{mL}(90 \mu \mathrm{M})]$ against this organism. Each of the test compounds were then evaluated at a range of concentrations varying from 3.125 to $50-100 \mu \mathrm{M}$, with the upper concentration dependent upon the compounds intrinsic MIC towards $P$. aeruginosa. From all the compounds examined (Table 2), 5-bromoindole $\mathbf{4}$ and 7-fluoroindole $\mathbf{8}$ analogues were the most effective potentiators (restoring the action of doxycycline at $3.125 \mu \mathrm{M})$, followed closely by 7-methoxy $24(3.75 \mu \mathrm{M})$ with 6chloroindole 10, 7-methylcarboxylateindole 17, 5-methylindole 18, and 7-methylindole 19 analogues being equipotent $(6.25 \mu \mathrm{M})$ to our original hit compound $\mathbf{3}$.

\section{Table 2}

Doxycycline potentiation activity of analogues 3-24.

\begin{tabular}{|c|c|c|c|}
\hline Compound & Conc $(\mu \mathrm{M})$ for potentiation ${ }^{a}$ & Compound & Conc $(\mu \mathrm{M})$ for potentiation ${ }^{a}$ \\
\hline 3 & $6.25^{b}$ & 14 & 50 \\
\hline 4 & 3.125 & 15 & 25 \\
\hline 5 & 25 & 16 & 25 \\
\hline 6 & 12.5 & 17 & 6.25 \\
\hline 7 & 25 & 18 & 6.25 \\
\hline 8 & 3.125 & 19 & 6.25 \\
\hline 9 & 14.9 & 20 & 35 \\
\hline 10 & 6.25 & 21 & $>50$ \\
\hline 11 & 25 & 22 & 12.5 \\
\hline 12 & 100 & 23 & 50 \\
\hline 13 & 50 & 24 & 3.75 \\
\hline
\end{tabular}

${ }^{\text {a }}$ Concentration $(\mu \mathrm{M})$ required to restore doxycycline activity at $2 \mu \mathrm{g} / \mathrm{mL}(4.5 \mu \mathrm{M})$ against $P$. aeruginosa ATCC27853.

${ }^{\mathrm{b}}$ Data taken from Li et al. [13].

The spectrum of potentiation of the 5-bromoindole $\mathbf{4}$ and 7-methoxyindole $\mathbf{2 4}$ analogues was then evaluated for the antibiotics doxycycline, erythromycin, chloramphenicol and nalidixic acid against four Gram-negative ESKAPE pathogens $P$. aeruginosa ATCC27853, E. coli ATCC25922, K. pneumoniae ATCC13443 and A. baumannii AYE. In addition to original hit compound $\mathbf{3}$, both compounds enhanced the action of doxycycline towards E. coli and A. baumannii (Table 3). Interestingly the two bromo analogues (6-bromo 3 and 5-bromo 4) enhanced the action of doxycycline, and to a lesser degree nalidixic acid, towards K. pneumoniae. 


\section{Table 3}

Antibiotic potentiating activity of analogues $3, \mathbf{4}$ and 24 .

\begin{tabular}{|c|c|c|c|c|c|}
\hline \multirow{3}{*}{ Antibiotic } & \multirow{2}{*}{ Compound } & \multicolumn{4}{|c|}{ Concentration $(\mu \mathrm{M})$ for potentiation $^{a}$} \\
\cline { 2 - 6 } Doxycycline & $\mathbf{3}$ & $12.5^{f}$ & $6.25^{f}$ & $6.25^{f}$ & $25^{f}$ \\
\cline { 2 - 6 } & $\mathbf{4}$ & 6.25 & 1.68 & 13.4 & 6.72 \\
\cline { 2 - 6 } & $\mathbf{2 4}$ & 7.50 & 3.75 & $>200$ & 15 \\
\hline \multirow{3}{*}{ Erythromycin } & $\mathbf{3}$ & $200^{f}$ & $50^{f}$ & $50^{f}$ & $25^{f}$ \\
\cline { 2 - 6 } & $\mathbf{4}$ & $>200$ & n.t. ${ }^{g}$ & n.t. & n.t. \\
\cline { 2 - 6 } & $\mathbf{2 4}$ & 100 & $>200$ & $>200$ & $>200$ \\
\cline { 2 - 6 } Chloramphenicol & $\mathbf{3}$ & $>200^{f}$ & $>200^{f}$ & $200^{f}$ & $>200^{f}$ \\
\cline { 2 - 6 } & $\mathbf{4}$ & 26.9 & n.t. & n.t. & n.t. \\
\hline \multirow{3}{*}{ Nalidixic acid } & $\mathbf{2 4}$ & 30.0 & $>200$ & $>200$ & $>200$ \\
\cline { 2 - 6 } & $\mathbf{4}$ & $50^{f}$ & $>200^{f}$ & $25^{f}$ & $200^{f}$ \\
\cline { 2 - 6 } & $\mathbf{2 4}$ & 6200 & 100 & 12.5 & 100 \\
\hline
\end{tabular}

${ }^{\text {a }}$ Concentration $(\mu \mathrm{M})$ of compound required to restore antibiotics activity at $2 \mu \mathrm{g} / \mathrm{mL}$ concentration of antibiotic.

${ }^{\mathrm{b}}$ Pseudomonas aeruginosa ATCC27853 against doxycycline (MIC $90 \mu \mathrm{M}$ ), erythromycin (MIC $>200 \mu \mathrm{M}$ ), chloramphenicol (MIC $>200 \mu \mathrm{M})$ and nalidixic acid $(\mathrm{MIC}>200 \mu \mathrm{M})$ and values presented as the mean $(\mathrm{n}=$ $3)$.

c Escherichia coli ATCC25922 against doxycycline (MIC $25 \mu \mathrm{M}$ ) erythromycin (MIC >200 $\mu \mathrm{M}$ ), chloramphenicol (MIC $>200 \mu \mathrm{M})$ and nalidixic acid $(\mathrm{MIC}>200 \mu \mathrm{M})$ and values presented as the mean $(\mathrm{n}=$ $3)$.

${ }^{\mathrm{d}}$ Klebsiella pneumoniae ATCC13443 against doxycycline (MIC $25 \mu \mathrm{M}$ ) erythromycin (MIC $>200 \mu \mathrm{M}$ ), chloramphenicol (MIC $50 \mu \mathrm{M})$ and nalidixic acid (MIC $100 \mu \mathrm{M})$ and values presented as the mean $(\mathrm{n}=3)$.

e Acinetobacter baumannii AYE against doxycycline (MIC $12.5 \mu \mathrm{M}$ ) erythromycin (MIC $200 \mu \mathrm{M}$ ), chloramphenicol $(\mathrm{MIC}>200 \mu \mathrm{M})$ and nalidixic acid $(\mathrm{MIC}>200 \mu \mathrm{M})$ and values presented as the mean $(\mathrm{n}=$ $3)$.

${ }^{\mathrm{f}}$ Data taken from Li et al. [13].

${ }^{\mathrm{g}}$ Not tested.

The cytotoxicity of compounds 3-24 were evaluated against rat skeletal muscle (L6) and human embryonic kidney (HEK-293) cell lines. Other than the previously reported lead compound $\mathbf{3}$, only the 5,6-dibromoindole (5) and 7-chloroindole (11) analogues exhibited cytotoxicity against L6 cells $\left(\mathrm{IC}_{50} 6.03\right.$ and $7.47 \mu \mathrm{M}$, respectively) with all other compounds being weakly cytotoxic with $\mathrm{IC}_{50}$ values ranging from 19.8 to $>100$ $\mu \mathrm{M}$ (Table 4). The HEK-293 cell line testing identified 5-chloroindole 9, 6-trifluoromethylindole 12 and 7methylcarboxylateindole $\mathbf{1 7}$ as also exhibiting cytotoxicity. Pronounced haemolytic activity towards rat red blood cells was observed for 6-bromoindole 3 with an $\mathrm{HC}_{50}$ (concentration at which $50 \%$ of red blood cells 
were lysed) of $20 \mu \mathrm{M}$, and for 5,6-dibromoindole $5\left(\mathrm{HC}_{50} 17 \mu \mathrm{M}\right)$, with weaker activity observed for 5bromoindole 4, 6-chloroindole 10 and 7-methylcarboxylateindole 17 (Table 4). Modest to no haemolytic activities were observed for the other compounds in the library. Combined analysis of doxycycline potentiating activity with cytotoxicity and haemolytic data for the test compounds identified five analogues of particular interest (i.e. antibiotic potentiating with limited/no cytotoxicity and haemolytic properties): 5-bromoindole 4 [3.125 $\mu \mathrm{M}$ potentiation, weakly cytotoxic $\mathrm{IC}_{50} 14.1-19.8 \mu \mathrm{M}$, and modestly haemolytic $(34.7 \%$ haemolysis at $50 \mu \mathrm{M})$ ], 7-fluoroindole 8 [3.125 $\mu \mathrm{M}, \mathrm{IC}_{50} 18.7-38.7 \mu \mathrm{M}, 8.4 \%$ haemolysis at $50 \mu \mathrm{M}$ ], 5-methylindole $\mathbf{1 8}$ [6.25 $\mu \mathrm{M}, \mathrm{IC}_{50} 63.8 \mu \mathrm{M}, 0.3 \%$ at $\left.50 \mu \mathrm{M}\right]$, 7-methylindole $19\left[6.25 \mu \mathrm{M}, \mathrm{IC}_{50} 59.6 \mu \mathrm{M}, 0.1 \%\right.$ at $\left.50 \mu \mathrm{M}\right]$ and 7methoxyindole analogue $24\left[3.75 \mu \mathrm{M}, \mathrm{IC}_{50} 27-62 \mu \mathrm{M}\right.$ and not haemolytic $(0 \%$ at $\left.50 \mu \mathrm{M})\right]$.

\section{Table 4}

Cytotoxic and haemolytic properties of analogues 3-24.

\begin{tabular}{|c|c|c|c|}
\hline \multirow[b]{2}{*}{ Compound } & \multicolumn{2}{|c|}{ Cytotoxicity } & \multirow{2}{*}{$\begin{array}{c}\text { Haemolysis } \\
\% \text { haemolysis } \\
\text { at } 50 \mu \mathrm{M} \\
\left(\mathrm{HC}_{50} \mu \mathrm{M}\right)^{c}\end{array}$} \\
\hline & $\begin{array}{c}\mathbf{L 6}^{a}{ }^{\text {I }} \mathbf{C}_{50} \\
(\boldsymbol{\mu M})\end{array}$ & $\underset{(\mu \mathrm{M})}{\operatorname{HEK-293}}{ }^{b} \mathrm{CC}_{50}$ & \\
\hline 3 & $7.7^{d}$ & $5.06^{e}$ & $91(20)$ \\
\hline 4 & 19.8 & 14.1 & 34.7 \\
\hline 5 & 6.03 & 1.62 & 88.7 (17) \\
\hline 6 & 71.1 & $>39.6$ & 0 \\
\hline 7 & 69.1 & 12.5 & 0.3 \\
\hline 8 & 38.7 & 18.7 & 8.4 \\
\hline 9 & 19.8 & 4.73 & 0 \\
\hline 10 & 33.2 & 19.1 & 11.6 \\
\hline 11 & 7.47 & 31.6 & 1.1 \\
\hline 12 & 31.4 & 3.36 & 3.2 \\
\hline 13 & 37.1 & $>38.9$ & 0 \\
\hline 14 & 46.9 & $>38.9$ & 0 \\
\hline 15 & 41.8 & $>36.0$ & 0 \\
\hline 16 & 63.6 & $>36.0$ & 0.6 \\
\hline 17 & 34.4 & 3.78 & 15.0 \\
\hline 18 & 63.8 & $>40.0$ & 0.3 \\
\hline 19 & 59.6 & $>40.0$ & 0.1 \\
\hline 20 & 167 & $>55$ & 0.3 \\
\hline 21 & $60^{d}$ & $>41.5$ & 0 \\
\hline 22 & $56^{d}$ & $>38.4$ & 0 \\
\hline 23 & $54^{d}$ & $>38.4$ & 0 \\
\hline 24 & $62^{d}$ & 27.1 & 0 \\
\hline
\end{tabular}

${ }^{a}$ L6 rat skeletal myoblast cell line with podophyllotoxin as the positive control $\left(\mathrm{IC}_{50} 0.018 \mu \mathrm{M}\right)$ and values presented as the mean $(n=2)$. 
${ }^{\mathrm{b}}$ Concentration of compound at 50\% cytotoxicity on HEK293 human embryonic kidney cells and values presented as the mean $(\mathrm{n}=2)$. Highest dose tested was $32 \mu \mathrm{g} / \mathrm{mL}$.

${ }^{\mathrm{c}}$ Percentage haemolysis detected at $540 \mathrm{~nm}$ at $50 \mu \mathrm{M}$ concentration of compound with $0.1 \%$ Triton $\mathrm{X}-100$ as the positive control $(100 \%$ hemolysis) with values presented as the mean $(\mathrm{n}=3)$. Where given the value in parenthesis is the concentration $(\mu \mathrm{M})$ of compound required to induce $50 \%$ haemolysis.

${ }^{\mathrm{d}}$ Data taken from Wang et al. [15]

${ }^{\mathrm{e}}$ Data taken from Li et al. [13].

Potential mechanisms of antibiotic potentiation include permeabilization of the outer membrane or membrane depolarization [9][10]. Compounds $\mathbf{4}$ and $\mathbf{8}$ were selected as the model compounds for these studies due to their abilities to potently enhance the action of antibiotics but with only limited cytotoxic/haemolytic properties. In the first set of studies, a bioluminescence method was used to detect extra-cellular concentrations of ATP that resulted from membrane permeabilization. Brief exposure $(1 \mathrm{~min})$ of either compound to bacterial cells induced dose-dependent increases in extracellular ATP levels in both $S$. aureus (Figure 3 left) and, to a lesser extent, in $P$. aeruginosa (Figure 3 right) suggesting both polyamine derivatives can disrupt the integrity of bacterial membranes. Both compounds were less effective than the known membrane disrupting steroidalpolyamine squalamine [16].
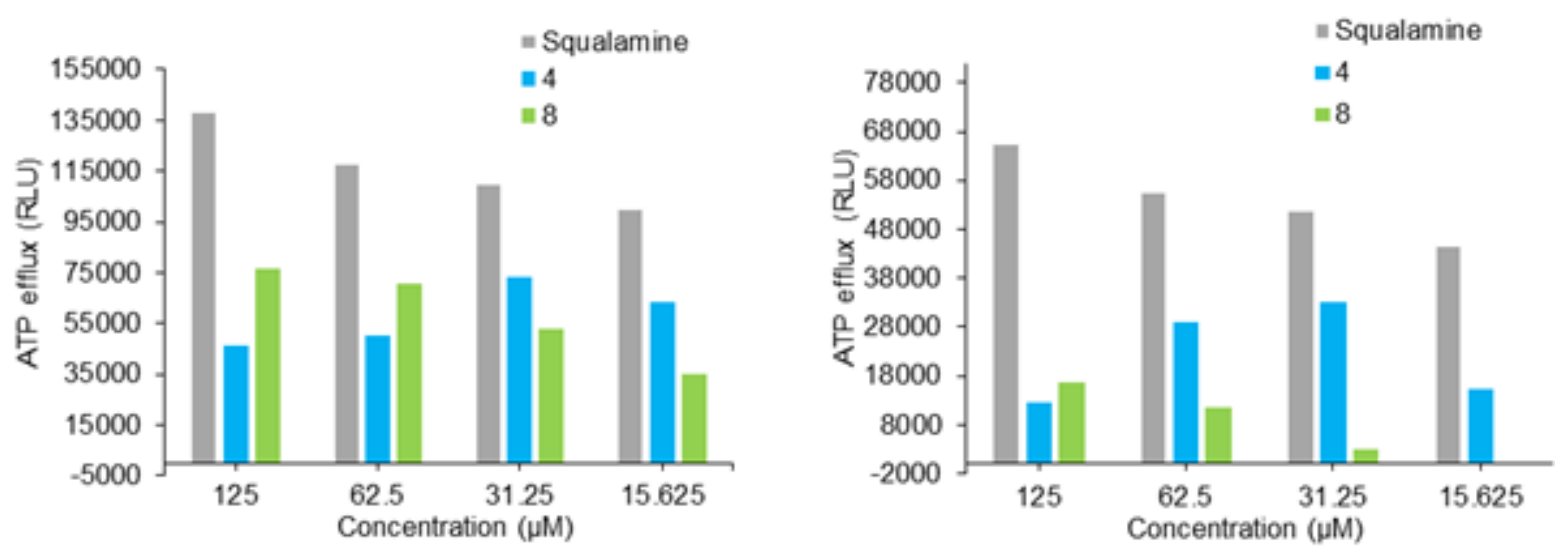

Fig. 3. Dose-dependent ATP release for $S$. aureus (left) and P. aeruginosa (right) exhibited by $\mathbf{4}$ and $\mathbf{8}$ with squalamine as the positive control.

Further evidence for the ability of the test compounds to disrupt the outer bacterial membrane was determined in the Gram-negative bacterium Enterobacter aerogenes EA289 using a nitrocefin colorimetric assay. The 
basis of this assay is that membrane disruption leads to ingress of a chromogenic cephalosporin that acts as a substrate for periplasmic $\beta$-lactamase, whereupon $\beta$-lactam hydrolysis leads to a color change from yellow to red. As presented in Figure 4, dose-dependent effect on the rate of nitrocefin hydrolysis was observed for both 4 and $\mathbf{8}$, with the former being more potent.

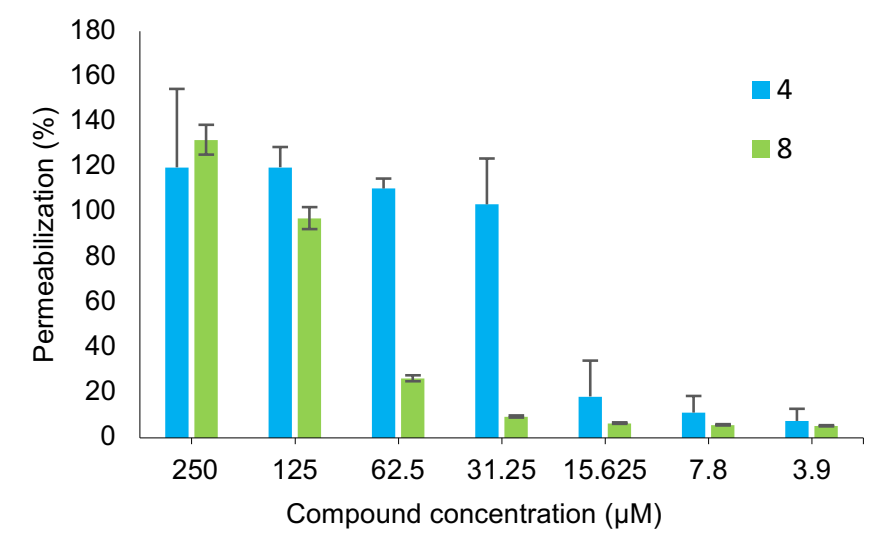

Fig. 4. Dose-dependent effect of $\mathbf{4}$ and $\mathbf{8}$ on the rate of nitrocefin hydrolysis in E. aerogenes EA289 resulting from outer membrane permeabilization.

Many drug efflux pumps function via an energy-dependent mechanism that makes use of membrane proton gradients [17][18]. Compounds $\mathbf{4}$ and $\mathbf{8}$ were investigated for their ability to act as disruptors of the bacterial transmembrane potential by using the membrane-potential-sensitive probe $\mathrm{DiSC}_{3}(5)$ which concentrates at the inner membrane level and quenches its own fluorescence. When a compound impairs the membrane potential, the dye is released leading to an increase in fluorescence. After 15 min incubation, modest membrane depolarization was observed against Gram-positive $S$. aureus (Figure 5 left) and Gram-negative $P$. aeruginosa (Figure 5 right) strains for both $\mathbf{4}$ and 8 . 

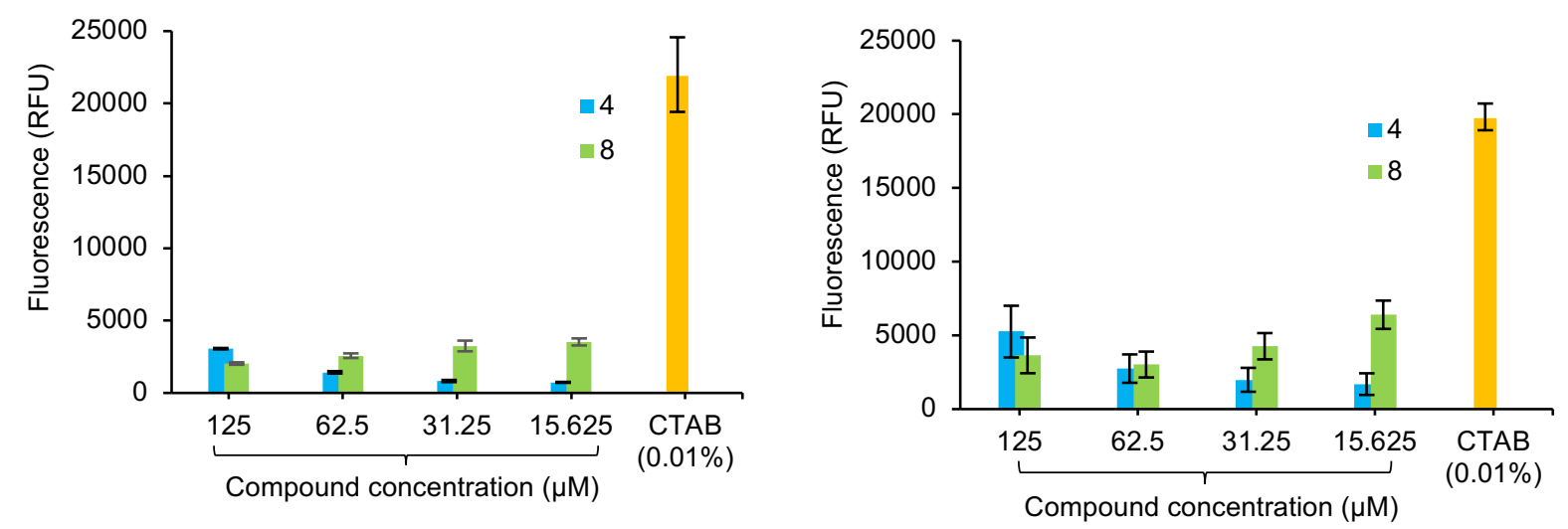

Fig. 5. Dose-dependent depolarization by 4 and $\mathbf{8}$ of the bacterial membranes of $S$. aureus (left) and $P$. aeruginosa (right) with cetyltrimethylammonium bromide (CTAB) $(0.01 \%)$ as the positive control.

Collectively the ATP release, nitrocefin hydrolysis and $\mathrm{DiSC}_{3}(5)$ membrane potential assay results suggest that the intrinsic antimicrobial activities of compounds $\mathbf{4}$ and $\mathbf{8}$ could be due to their abilities to disrupt bacterial membranes while their antibiotic potentiating activities may stem from their ability to depolarize membranes leading to efflux pump inhibition.

\section{Conclusions}

Our previous screening identified $N^{1}, N^{14}$-di-(6-bromoindolglyoxylamido)-spermine to be a potent enhancer of the action of doxycycline towards $P$. aeruginosa and that the polyamine core of the molecule was essential for activity. A limitation of the compound however was the observation of cytotoxicity and haemolytic properties. The present study has expanded this structure-activity relationship to include variation of substituents on the indolglyoxylamide head-group. Of note was the discovery of four analogues, bearing 7 methoxy, 7-fluoro, 7-methyl or 5-methyl indole substitution, that were either equipotent or more potent in their ability to enhance the action of doxycycline than the original hit compound. The relative location of these substituents appears to be a critical factor for potentiating activity. Of these four new potentiators, the 7methoxy, 5-methyl and 7-methyl substituted variants were 3-10-fold less cytotoxic and had little or negligible haemolytic effect on red blood cells. Cell-based assays identified the 5-bromo and 7-fluoro analogues as being capable of permeabilizing bacterial membranes, likely having a bearing on their intrinsic antibacterial properties, while both were also capable of depolarizing membranes, a possible cause of their antibiotic 
potentiating activities. Current studies are directed towards the discovery of more potent antibiotic enhancers and their evaluation in in vivo models of infection.

\section{Experimental}

\subsection{Chemistry: General methods}

Infrared spectra were recorded on a Perkin-Elmer spectrometer 100 Fourier Transform infrared spectrometer equipped with a universal ATR accessory. HRMS data were acquired on a Bruker micrOTOF QII spectrometer. NMR spectra were recorded on a Bruker Avance DRX-400 spectrometer operating at 400 $\mathrm{MHz}$ for ${ }^{1} \mathrm{H}$ nuclei and $100 \mathrm{MHz}$ for ${ }^{13} \mathrm{C}$ nuclei. Proto-deutero solvent signals were used as internal references (DMSO- $d_{6}: \delta_{\mathrm{H}} 2.50, \delta_{\mathrm{C}} 39.52$ ). For ${ }^{1} \mathrm{H}$ NMR, the data are quoted as position ( $\delta$ ), relative integral, multiplicity ( $\mathrm{s}=$ singlet, $\mathrm{d}=$ doublet, $\mathrm{t}=$ triplet, $\mathrm{q}=$ quartet, $\mathrm{m}=$ multiplet, $\mathrm{br}=$ broad $)$, coupling constant $(J, \mathrm{~Hz})$, and assignment to the atom. The ${ }^{13} \mathrm{C}$ NMR data are quoted as position $(\delta)$, and assignment to the atom. Flash column chromatography was carried out using either Davisil silica gel (40-60 $\mu \mathrm{m})$ or Merck LiChroprep RP$8(40-63 \mu \mathrm{m})$. Thin layer chromatography was conducted on Merck DC Kieselgel 60 RP-18 F254S plates. All solvents used were of analytical grade or better and/or purified according to standard procedures. Chemical reagents used were purchased from standard chemical suppliers and used as purchased. Di-tert-butyl butane1,4-diylbis((3-aminopropyl)carbamate) [19], 5,6-dibromoindole [20], 2-(4-fluoro-1H-indol-3-yl)-2-oxoacetic acid [14], and 21-24 [15] were prepared according to a literature procedures.

\subsection{Synthesis of compounds}

\subsubsection{General procedure A - synthesis of substituted 3-indolglyoxylyl chlorides.}

To a solution of indole (1 equiv.) in anhydrous diethyl ether $(12 \mathrm{~mL})$ was added oxalyl chloride (1.15 equiv.) at $0{ }^{\circ} \mathrm{C}$ under $\mathrm{N}_{2}$ atmosphere. The reaction mixture was stirred for $3 \mathrm{~h}$ before solvent removal under reduced pressure. The product was used in the next step without purification.

\subsubsection{General procedure B - Coupling of 3-indolglyoxylyl chlorides with Boc protected polyamine.}

To a solution of 3-indolglyoxylyl chloride (2 equiv.) in DMF (1 mL) was added DIPEA (6 equiv.) and di-tertbutyl butane-1,4-diylbis((3-aminopropyl)carbamate) (1 equiv.) in DMF $(1 \mathrm{~mL})$. Subsequently, the reaction 
mixture was stirred for $48 \mathrm{~h}$ before solvent removal under reduced pressure. The crude product was purified using silica gel flash column chromatography $\left(3 \% \mathrm{MeOH}: \mathrm{CH}_{2} \mathrm{Cl}_{2}\right)$.

\subsubsection{General procedure C-Boc deprotection.}

A solution of tert-butyl-carbamate derivative in $\mathrm{CH}_{2} \mathrm{Cl}_{2}(2 \mathrm{~mL})$ and TFA $(0.2 \mathrm{~mL})$ was stirred at room temperature under $\mathrm{N}_{2}$ for $2 \mathrm{~h}$ followed by solvent removal under reduced pressure. The crude product was purified using $\mathrm{C}_{8}$ reversed-phase flash column chromatography eluting with $0 \%-50 \% \mathrm{MeOH} / \mathrm{H}_{2} \mathrm{O}(0.05 \%$ TFA) to afford the corresponding polyamine as a TFA salt.

5.2.3.1. $\quad N^{l}, N^{4}$-Bis(3-(2-(5-bromo-1H-indol-3-yl)-2-oxoacetamido) propyl)butane-1,4-diaminium 2,2,2trifluoroacetate (4)

Using general procedure A, reaction of 5-bromo- $1 H$-indole (392 $\mathrm{mg}, 2 \mathrm{mmol}$ ) and oxalyl chloride (0.195 mL, $2.3 \mathrm{mmol})$ afforded 2-(5-bromo-1H-indol-3-yl)-2-oxoacetyl chloride as a yellow powder. Using general procedure $\mathrm{B}$, a sub-sample of the glyoxylyl chloride $(71.1 \mathrm{mg}, 0.248 \mathrm{mmol})$ was reacted with di-tertbutyl butane-1,4-diylbis((3-aminopropyl)carbamate) $(50 \mathrm{mg}, 0.124 \mathrm{mmol})$ and DIPEA $(0.130 \mathrm{~mL}, 0.744$ $\mathrm{mmol})$ in DMF $(2 \mathrm{~mL})$ to afford, after chromatography, di-tert-butyl butane-1,4-diylbis((3-(2-(5-bromo- $1 \mathrm{H}$ indol-3-yl)-2-oxoacetamido)propyl)carbamate) as a yellow gum (36 mg, 38\%). Using general procedure C, a sub-sample of this material $(36 \mathrm{mg}, 0.040 \mathrm{mmol}$ ) was deprotected to afford the di-TFA salt of 4 as a brown oil (36 mg, quant. yield) which required no further purification. $\mathrm{R}_{\mathrm{f}}(\mathrm{MeOH} / 10 \% \mathrm{HCl}, 7: 3)$ 0.63; IR (ATR) $v_{\max }$ 3152, 2981, 1671, 1623, 1501, 1430, 1199, $1130 \mathrm{~cm}^{-1}$; ${ }^{1} \mathrm{H}$ NMR (DMSO- $\left.d_{6}, 400 \mathrm{MHz}\right) \delta 12.49$ (2H, br s, NH1, NH-1'), 8.92 (2H, t, $\left.J=6.1 \mathrm{~Hz}, \mathrm{NH}-10, \mathrm{NH}-10^{\prime}\right), 8.80$ (2H, d, $\left.J=3.3 \mathrm{~Hz}, \mathrm{H}-2, \mathrm{H}-2^{\prime}\right), 8.55$ (4H, br s, $\mathrm{NH}_{2}-$ 14, $\left.\mathrm{NH}_{2}-14^{\prime}\right), 8.35$ (2H, d, $\left.J=1.9 \mathrm{~Hz}, \mathrm{H}-4, \mathrm{H}^{\prime} 4^{\prime}\right), 7.53$ (2H, d, $\left.J=8.7 \mathrm{~Hz}, \mathrm{H}-7, \mathrm{H}-7^{\prime}\right), 7.42$ (2H, dd, $J=4.3$, 1.7 Hz, H-6, H-6'), 3.33-3.26 (4H, m, H2-11, H $\left.\mathrm{H}_{2}-11^{\prime}\right), 3.00-2.88$ (8H, m, H2-13, $\left.\mathrm{H}_{2}-13^{\prime}, \mathrm{H}_{2}-15, \mathrm{H}_{2}-15^{\prime}\right), 1.89-$ 1.81 (4H, m, H $\left.\mathrm{H}_{2}-12, \mathrm{H}_{2}-12^{\prime}\right), 1.67-1.57$ (4H, m, $\left.\mathrm{H}_{2}-16, \mathrm{H}_{2}-16^{\prime}\right) ;{ }^{13} \mathrm{C}$ NMR (DMSO-d $\left.6,100 \mathrm{MHz}\right) \delta 181.7$ (C8, C-8'), 163.4 (C-9, C-9'), 139.5 (C-2, C-2'), 135.1 (C-7a, C-7a'), 128.1 (C-3a, C-3a'), 126.2 (C-6, C-6'), 123.4 (C-4, C-4'), 115.4 (C-5, C-5'), 114.8 (C-7, C-7'), 111.6 (C-3, C-3'), 46.1 (C-15, C-15'), 44.8 (C-13, C-13'), 35.9 (C-11, C-11'), 25.7 (C-12, C-12'), 22.8 (C-16, C-16'); (+)-HRESIMS [M+Na] $]^{+} \mathrm{m} / z 723.0912$ (calcd for $\mathrm{C}_{30} \mathrm{H}_{34}{ }^{79} \mathrm{Br}_{2} \mathrm{~N}_{6} \mathrm{O}_{4} \mathrm{Na}, 723.0900$ ), 725.0909 (calcd for $\mathrm{C}_{30} \mathrm{H}_{34}{ }^{79} \mathrm{Br}^{81} \mathrm{BrN}_{6} \mathrm{O}_{4} \mathrm{Na}, 725.0883$ ), 727.0885 (calcd for $\left.\mathrm{C}_{30} \mathrm{H}_{34}{ }^{81} \mathrm{Br}_{2} \mathrm{~N}_{6} \mathrm{O}_{4} \mathrm{Na}, 727.0869\right)$.

5.2.3.2. $N^{1}, N^{4}$-Bis(3-(2-(5,6-dibromo-1H-indol-3-yl)-2-oxoacetamido) propyl)butane-1,4-diaminium 2,2,2trifluoroacetate (5)

Using general procedure A, reaction of 5,6-dibromo- $1 H$-indole [20] (207 $\mathrm{mg}, 0.75 \mathrm{mmol})$ and oxalyl chloride $(0.087 \mathrm{~mL}, 0.90 \mathrm{mmol})$ afforded 2-(5,6-dibromo- $1 H$-indol-3-yl)-2-oxoacetyl chloride as a yellow 
powder. Using general procedure B, a sub-sample of the glyoxylyl chloride (105 $\mathrm{mg}, 0.289 \mathrm{mmol})$ was reacted with di-tert-butyl butane-1,4-diylbis((3-aminopropyl)carbamate) (50 mg, $0.124 \mathrm{mmol})$ and DIPEA (0.130 mL, $0.744 \mathrm{mmol})$ in DMF $(2 \mathrm{~mL})$ to afford, after chromatography, di-tert-butyl butane-1,4-diylbis((3-(2-(5,6dibromo-1 $H$-indol-3-yl)-2-oxoacetamido)propyl)carbamate) as a yellow oil (39 $\mathrm{mg}, 41 \%$ ). Using general procedure $\mathrm{C}$, this material ( $39 \mathrm{mg}, 0.037 \mathrm{mmol}$ ) was deprotected to afford the di-TFA salt of 5 as a red oil (25 $\mathrm{mg}, 78 \%)$. $\mathrm{R}_{\mathrm{f}}(\mathrm{MeOH} / 10 \% \mathrm{HCl}, 7: 3)$ 0.15; IR (ATR) $v_{\max }$ 3350, 3104, 2259, 1672, 1623, 1439, 1199, 1180 , $1127 \mathrm{~cm}^{-1} ;{ }^{1} \mathrm{H}$ NMR (DMSO- $\left.d_{6}, 400 \mathrm{MHz}\right) \delta 12.57$ (2H, d, $J=2.7 \mathrm{~Hz}, \mathrm{NH}-1, \mathrm{NH}-1$ '), 8.95 (2H, t, $J=5.9 \mathrm{~Hz}$, NH-10, NH-10'), 8.84 (2H, d, J=3.1 Hz, H-2, H-2'), 8.61 (4H, br s, NH2-14, NH2-14'), 8.53 (2H, s, H-4, H4'), 7.99 (2H, s, H-7, H-7'), 3.34-3.26 (4H, m, H $\left.\mathrm{H}_{2}-11, \mathrm{H}_{2}-11^{\prime}\right), 3.00-2.90$ (8H, m, H2-13, H2-13', $\mathrm{H}_{2}-15, \mathrm{H}_{2}-$ 15'), 1.91-1.81 (4H, m, $\left.\mathrm{H}_{2}-12, \mathrm{H}_{2}-12^{\prime}\right), 1.67-1.60$ (4H, m, $\mathrm{H}_{2}-16, \mathrm{H}_{2}-16$ ) $;{ }^{13} \mathrm{C}$ NMR (DMSO- $\left.d_{6}, 100 \mathrm{MHz}\right) \delta$ 181.6 (C-8, C-8'), 163.1 (C-9, C-9'), 140.4 (C-2, C-2'), 136.1 (C-7a, C-7a'), 127.1 (C-3a, C-3a'), 125.2 (C-4, C-4'), 117.6 (C-7, C-7', C-5/C-6, C-5'/C-6'), 117.3 (C-5/C-6, C-5'/C-6'), 111.4 (C-3, C-3'), 46.1 (C-15, C-15'), 44.7 (C-13, C-13'), 35.9 (C-11, C-11'), 25.6 (C-12, C-12'), 22.7 (C-16, C-16'); (+)-HRESIMS [M+H] $]^{+} \mathrm{m} / \mathrm{z}$ 856.9308 (calcd for $\mathrm{C}_{30} \mathrm{H}_{33}{ }^{79} \mathrm{Br}_{4} \mathrm{~N}_{6} \mathrm{O}_{4}, 856.9291$ ), 858.9293 (calcd for $\mathrm{C}_{30} \mathrm{H}_{33}{ }^{79} \mathrm{Br}_{3}{ }^{81} \mathrm{BrN}_{6} \mathrm{O}_{4}, 858.9272$ ), 860.9278 (calcd for $\mathrm{C}_{30} \mathrm{H}_{33}{ }^{79} \mathrm{Br}_{2}{ }^{81} \mathrm{Br}_{2} \mathrm{~N}_{6} \mathrm{O}_{4}, 860.9254$ ), 862.9261 (calcd for $\mathrm{C}_{30} \mathrm{H}_{33}{ }^{79} \mathrm{Br}^{81} \mathrm{Br}_{3} \mathrm{~N}_{6} \mathrm{O}_{4}, 862.9237$ ), 864.9248 (calcd for $\mathrm{C}_{30} \mathrm{H}_{33}{ }^{81} \mathrm{Br}_{4} \mathrm{~N}_{6} \mathrm{O}_{4}, 864.9226$ ).

\subsubsection{3. $N^{l}, N^{4}$-Bis(3-(2-(5-fluoro-1H-indol-3-yl)-2-oxoacetamido)propyl)butane-1,4-diaminium 2,2,2- trifluoroacetate (6)}

Using general procedure A, reaction of 5-fluoro- $1 H$-indole $(270 \mathrm{mg}, 2 \mathrm{mmol})$ and oxalyl chloride (0.195 mL, $2.3 \mathrm{mmol})$ afforded 2-(5-fluoro-1H-indol-3-yl)-2-oxoacetyl chloride as a yellow powder. Using general procedure $\mathrm{B}$, a sub-sample of the glyoxylyl chloride $(52 \mathrm{mg}, 0.251 \mathrm{mmol})$ was reacted with di-tertbutyl butane-1,4-diylbis((3-aminopropyl)carbamate) $(50 \mathrm{mg}, 0.124 \mathrm{mmol})$ and DIPEA $(0.130 \mathrm{~mL}, 0.744$ $\mathrm{mmol})$ in DMF (2 $\mathrm{mL})$ to afford, after silica gel column chromatography, di-tert-butyl butane-1,4-diylbis((3(2-(5-fluoro-1 $H$-indol-3-yl)-2-oxoacetamido)propyl)carbamate) as a yellow oil (72 $\mathrm{mg}, 74 \%$ ). Using general procedure $\mathrm{C}$, a sub-sample of this material $(37 \mathrm{mg}, 0.047 \mathrm{mmol})$ was then deprotected to afford the di-TFA salt of 6 as a yellow oil (28 mg, 76\%). $\mathrm{R}_{\mathrm{f}}(\mathrm{MeOH} / 10 \% \mathrm{HCl}, 7: 3)$ 0.42; IR (ATR) $v_{\max } 3384,2973,2109,1702$, 1647, 1368, $1231 \mathrm{~cm}^{-1}$; ${ }^{1} \mathrm{H}$ NMR (DMSO- $\left.d_{6}, 400 \mathrm{MHz}\right) \delta 12.39$ (2H, br s, NH-1, NH-1'), 8.92 (2H, t, $J=6.0$ Hz, NH-10, NH-10'), 8.81 (2H, d, $J=3.2$ Hz, H-2, H-2'), 8.49 (4H, br s, $\left.\mathrm{NH}_{2}-14, \mathrm{NH}_{2}-14{ }^{\prime}\right), 7.89$ (2H, dd, $J=$ 8.5, 2.6 Hz, H-4, H-4') 7.57 (2H, dd, $\left.J=8.9,4.3 \mathrm{~Hz}, \mathrm{H}-7, \mathrm{H}-7^{\prime}\right), 7.13$ (2H, ddd, J=9.2, 6.6, $2.7 \mathrm{~Hz}, \mathrm{H}-6, \mathrm{H}-$ 6'), 3.32-3.27 (4H, m, H $\left.\mathrm{H}_{2}-11, \mathrm{H}_{2}-11^{\prime}\right), 3.00-2.88$ (8H, m, $\left.\mathrm{H}_{2}-13, \mathrm{H}_{2}-13^{\prime}, \mathrm{H}_{2}-15, \mathrm{H}_{2}-15^{\prime}\right), 1.89-1.82$ (4H, m, $\mathrm{H}_{2}-$ $\left.12, \mathrm{H}_{2}-12^{\prime}\right), 1.67-1.53\left(4 \mathrm{H}, \mathrm{m}, \mathrm{H}_{2}-16, \mathrm{H}_{2}-16^{\prime}\right) ;{ }^{13} \mathrm{C}$ NMR (DMSO- $\left.d_{6}, 100 \mathrm{MHz}\right) \delta 181.7$ (C-8, C-8'), $163.6(\mathrm{C}-$ 9, C-9'), $159.2\left(\mathrm{~d},{ }^{1} J_{\mathrm{CF}}=251.2 \mathrm{~Hz}, \mathrm{C}-5, \mathrm{C}-5^{\prime}\right), 158.8$ (q, $\left.{ }^{2} J_{\mathrm{CF}}=25.5 \mathrm{~Hz}, \mathrm{C}-18, \mathrm{C}-18^{\prime}\right), 139.9$ (C-2, C-2'), 133.0 (C-7a, C-7a'), 127.0 (C-3a, C-3a'), $114.1\left(\mathrm{~d},{ }^{3} J_{\mathrm{CF}}=10.2 \mathrm{~Hz}, \mathrm{C}-7, \mathrm{C}-7^{\prime}\right), 112.3\left(\mathrm{C}-3, \mathrm{C}-3{ }^{\prime}\right), 111.7\left(\mathrm{~d},{ }^{2} J_{\mathrm{CF}}=25.6\right.$ $\left.\mathrm{Hz}, \mathrm{C}-6, \mathrm{C}^{6} 6^{\prime}\right), 106.3$ (d, $\left.{ }^{2} J_{\mathrm{CF}}=25.5 \mathrm{~Hz}, \mathrm{C}-4, \mathrm{C}-4^{\prime}\right), 46.2$ (C-15, C-15'), 44.9 (C-13, C-13'), 35.9 (C-11, C-11'), $25.8\left(\mathrm{C}-12, \mathrm{C}-12^{\prime}\right), 22.8\left(\mathrm{C}-16, \mathrm{C}-16^{\prime}\right) ;(+)$-HRESIMS $[\mathrm{M}+\mathrm{H}]^{+} m / z 581.2682$ (calcd for $\mathrm{C}_{30} \mathrm{H}_{35} \mathrm{~F}_{2} \mathrm{~N}_{6} \mathrm{O}_{4}$, $581.2682)$. 
5.2.3.4. $N^{1}, N^{4}$-Bis(3-(2-(6-fluoro-1H-indol-3-yl)-2-oxoacetamido) propyl)butane-1,4-diaminium 2,2,2trifluoroacetate (7)

Using general procedure A, reaction of 6-fluoro- $1 H$-indole $(270 \mathrm{mg}, 2 \mathrm{mmol})$ and oxalyl chloride $(0.195 \mathrm{~mL}, 2.3 \mathrm{mmol})$ afforded 2-(6-fluoro- $1 H$-indol-3-yl)-2-oxoacetyl chloride as a yellow powder. Using general procedure $\mathrm{B}$, a sub-sample of the glyoxylyl chloride $(52 \mathrm{mg}, 0.251 \mathrm{mmol})$ was reacted with di-tertbutyl butane-1,4-diylbis((3-aminopropyl)carbamate) $(50 \mathrm{mg}, 0.124 \mathrm{mmol})$ and DIPEA $(0.130 \mathrm{~mL}, 0.744$ mmol) in DMF (2 mL) to afford, after chromatography, di-tert-butylbutane-1,4-diylbis((3-(2-(6-fluoro-1Hindol-3-yl)-2-oxoacetamido)propyl)carbamate) as a yellow gum (62 mg, 64\%). Using general procedure C, a sub-sample of this material $(26 \mathrm{mg}, 0.033 \mathrm{mmol})$ was deprotected to afford the di-TFA salt of 7 as a yellow oil (16 mg, 65\%). $\mathrm{R}_{\mathrm{f}}(\mathrm{MeOH} / 10 \% \mathrm{HCl}, 7: 3)$ 0.41; IR (ATR) $v_{\max } 2963,2850,1672,1624,1513,1496,1447$, 1200, $1131 \mathrm{~cm}^{-1}$; ${ }^{1} \mathrm{H}$ NMR (DMSO- $\left.d_{6}, 400 \mathrm{MHz}\right) \delta 12.35$ (2H, br s, NH-1, NH-1'), 8.91 (2H, t, $J=6.1 \mathrm{~Hz}$, NH-10, NH-10'), 8.77 (2H, d, $J=3.0$ Hz, H-2, H-2'), 8.57 (4H, br s, $\mathrm{NH}_{2}-14, \mathrm{NH}_{2}-14$ '), 8.20 (2H, dd, $J=8.7$, 5.5 Hz, H-4, H-4'), 7.35 (2H, dd, $J=9.6,2.4$ Hz, H-7, H-7'), 7.12 (2H, td, $J=9.1,2.3$ Hz, H-5, H-5'), 3.34 3.27 (4H, m, H $\left.\mathrm{H}_{2}-11, \mathrm{H}_{2}-11^{\prime}\right), 3.00-2.90$ (8H, m, H $\left.\mathrm{H}_{2}-13, \mathrm{H}_{2}-13^{\prime}, \mathrm{H}_{2}-15, \mathrm{H}_{2}-15^{\prime}\right), 1.90-1.80$ (4H, m, H2-12, $\mathrm{H}_{2}-$ 12'), 1.66-1.57 (4H, m, $\left.\mathrm{H}_{2}-16, \mathrm{H}_{2}-16^{\prime}\right) ;{ }^{13} \mathrm{C}$ NMR (DMSO- $\left.d_{6}, 100 \mathrm{MHz}\right) \delta 181.8$ (C-8, C-8'), 163.5 (C-9, C9'), $160.0\left(\mathrm{~d},{ }^{1} J_{\mathrm{CF}}=237.1 \mathrm{~Hz}, \mathrm{C}-6, \mathrm{C}-6^{\prime}\right), 158.5$ (q, $\left.{ }^{2} J_{\mathrm{CF}}=34.5 \mathrm{~Hz}, \mathrm{C}-18, \mathrm{C}-18^{\prime}\right), 139.3$ (C-2, C-2'), 136.5 (d, $\left.{ }^{3} J_{\mathrm{CF}}=12.0 \mathrm{~Hz}, \mathrm{C}-7 \mathrm{a}, \mathrm{C}-7 \mathrm{a}^{\prime}\right), 122.9$ (C-3a, C-3a'), 122.4 (d, $\left.{ }^{3} J_{\mathrm{CF}}=9.9 \mathrm{~Hz}, \mathrm{C}-4, \mathrm{C}-4{ }^{\prime}\right), 112.1$ (C-3, C-3'), 110.8 $\left(\mathrm{d},{ }^{2} J_{\mathrm{CF}}=24.5 \mathrm{~Hz}, \mathrm{C}-5, \mathrm{C}-5^{\prime}\right), 99.1$ (d, $\left.{ }^{2} J_{\mathrm{CF}}=26.0 \mathrm{~Hz}, \mathrm{C}-7, \mathrm{C}-7^{\prime}\right), 46.1$ (C-15, C-15'), 44.7 (C-13, C-13'), 35.8 (C-11, C-11'), 25.7 (C-12, C-12'), 22.7 (C-16, C-16'); (+)-HRESIMS [M+H] $]^{+} \mathrm{m} / \mathrm{z} 581.2690$ (calcd for $\left.\mathrm{C}_{30} \mathrm{H}_{35} \mathrm{~F}_{2} \mathrm{~N}_{6} \mathrm{O}_{4}, 581.2682\right)$.

\subsubsection{5. $N^{1}, N^{4}$-Bis(3-(2-(7-fluoro-1H-indol-3-yl)-2-oxoacetamido) propyl)butane-1,4-diaminium 2,2,2- trifluoroacetate $(\boldsymbol{8})$}

Using general procedure A, reaction of 7-fluoro- $1 H$-indole $(270 \mathrm{mg}, 2 \mathrm{mmol})$ and oxalyl chloride (0.195 mL, $2.3 \mathrm{mmol})$ afforded 2-(7-fluoro-1H-indol-3-yl)-2-oxoacetyl chloride as a yellow powder. Using general procedure $\mathrm{B}$, a sub-sample of the glyoxylyl chloride $(62 \mathrm{mg}, 0.300 \mathrm{mmol})$ was reacted with di-tertbutyl butane-1,4-diylbis((3-aminopropyl)carbamate) $(50 \mathrm{mg}, 0.124 \mathrm{mmol})$ and DIPEA $(0.130 \mathrm{~mL}, 0.744$ $\mathrm{mmol})$ in DMF $(2 \mathrm{~mL})$ to afford, after chromatography, di-tert-butyl butane-1,4-diylbis((3-(2-(7-fluoro-1Hindol-3-yl)-2-oxoacetamido)propyl)carbamate) as a yellow gum (62 mg, 64\%). Using general procedure C, a sub-sample of this material ( $39 \mathrm{mg}, 0.050 \mathrm{mmol}$ ) was deprotected to afford the di-TFA salt of $\mathbf{8}$ as a brown oil (17 mg, 44\%). $\mathrm{R}_{\mathrm{f}}(\mathrm{MeOH} / 10 \% \mathrm{HCl}, 7: 3)$ 0.43; IR (ATR) $v_{\max } 3250,2840,1667,1606,1438,1200,1176,1126$ $\mathrm{cm}^{-1}$; ${ }^{1} \mathrm{H}$ NMR (DMSO- $\left.d_{6}, 400 \mathrm{MHz}\right) \delta 12.90$ (2H, d, $J=7.6 \mathrm{~Hz}, \mathrm{NH}-1, \mathrm{NH}-1$ '), 8.94 (2H, t, $J=6.0 \mathrm{~Hz}, \mathrm{NH}-$ 10, NH-10'), 8.78 (2H, d, J=3.1 Hz, H-2, H-2'), 8.59 (4H, br s, $\mathrm{NH}_{2}-14, \mathrm{NH}_{2}-14$ '), 8.04 (2H, d, J= 8.1 Hz, H4, H-4'), 7.25 (2H, ddd, $J=7.9,7.9,4.8$ Hz, H-5, H-5'), 7.13 (2H, dd, $J=11.2,7.9$ Hz, H-6, H-6'), 3.34-3.27 (4H, m, $\left.\mathrm{H}_{2}-11, \mathrm{H}_{2}-11^{\prime}\right), 3.00-2.90$ (8H, m, H $\mathrm{H}_{2}-13, \mathrm{H}_{2}-13$ ', $\left.\mathrm{H}_{2}-15, \mathrm{H}_{2}-15^{\prime}\right), 1.91-1.81$ (4H, m, H $\mathrm{H}_{2}-12, \mathrm{H}_{2}-12^{\prime}$ ), 
1.67-1.58 (4H, m, H2-16, $\left.\mathrm{H}_{2}-16^{\prime}\right) ;{ }^{13} \mathrm{C}$ NMR (DMSO-d $\left.6,100 \mathrm{MHz}\right) \delta 181.9$ (C-8, C-8'), 163.4 (C-9, C-9'), $158.4\left(\mathrm{q},{ }^{2} J_{\mathrm{CF}}=35.5 \mathrm{~Hz}, \mathrm{C}-18, \mathrm{C}-18^{\prime}\right), 149.2\left(\mathrm{~d},{ }^{1} J_{\mathrm{CF}}=245.7 \mathrm{~Hz}, \mathrm{C}-7, \mathrm{C}-7^{\prime}\right), 138.8\left(\mathrm{C}-2, \mathrm{C}-2^{\prime}\right), 129.8\left(\mathrm{~d},{ }^{3} J_{\mathrm{CF}}\right.$ $\left.=4.3 \mathrm{~Hz}, \mathrm{C}-3 \mathrm{a}, \mathrm{C}-3 \mathrm{a}^{\prime}\right), 124.0\left(\mathrm{~d},{ }^{2} J_{\mathrm{CF}}=13.3 \mathrm{~Hz}, \mathrm{C}-7 \mathrm{a}, \mathrm{C}-7 \mathrm{a}^{\prime}\right), 123.4$ (d, ${ }^{3} J_{\mathrm{CF}}=5.9 \mathrm{~Hz}, \mathrm{C}-5, \mathrm{C}-5$ ') $117.4(\mathrm{C}-4$, C-4'), 112.8 (C-3, C-3'), 108.7 (d, ${ }^{2} J_{\mathrm{CF}}=15.5 \mathrm{~Hz}, \mathrm{C}-6, \mathrm{C}-6$ '), 46.1 (C-15, C-15'), 44.7 (C-13, C-13'), 35.9 (C11, C-11'), 25.6 (C-12, C-12'), 22.7 (C-16, C-16'); (+)-HRESIMS [M+H] $]^{+} \mathrm{m} / z 581.2679$ (calcd for $\left.\mathrm{C}_{30} \mathrm{H}_{35} \mathrm{~F}_{2} \mathrm{~N}_{6} \mathrm{O}_{4}, 581.2682\right)$.

5.2.3.6. $N^{1}, N^{4}$-Bis(3-(2-(5-chloro-1H-indol-3-yl)-2-oxoacetamido)propyl)butane-1,4-diaminium 2,2,2trifluoroacetate (9)

Using general procedure A, reaction of 5-chloro- $1 H$-indole (303 $\mathrm{mg}, 2 \mathrm{mmol})$ and oxalyl chloride $(0.195 \mathrm{~mL}, 2.3 \mathrm{mmol})$ afforded 2-(5-chloro- $1 H$-indol-3-yl)-2-oxoacetyl chloride as a yellow powder. Using general procedure B, a sub-sample of the glyoxylyl chloride $(60 \mathrm{mg}, 0.248 \mathrm{mmol})$ was reacted with di-tertbutyl butane-1,4-diylbis((3-aminopropyl)carbamate) $(50 \mathrm{mg}, 0.124 \mathrm{mmol})$ and DIPEA $(0.130 \mathrm{~mL}, 0.744$ mmol) in DMF (2 mL) to afford, after chromatography, di-tert-butyl butane-1,4-diylbis((3-(2-(5-chloro- $1 H$ indol-3-yl)-2-oxoacetamido)propyl)carbamate) as a yellow gum (10 mg, 10\%). Using general procedure C, this material (10 mg, $0.012 \mathrm{mmol})$ was deprotected to afford the di-TFA salt of 9 as a brown oil $(5.0 \mathrm{mg}, 67 \%)$. $\mathrm{R}_{\mathrm{f}}(\mathrm{MeOH} / 10 \% \mathrm{HCl}, 7: 3)$ 0.43; IR (ATR) $v_{\max } 3374,2977,1676,1426,1132,1034,953,817,723 \mathrm{~cm}^{-1} ;{ }^{1} \mathrm{H}$ NMR (400 MHz, DMSO- $\left.d_{6}\right) \delta 12.52\left(2 \mathrm{H}, \mathrm{d}, J=3.3 \mathrm{~Hz}, \mathrm{NH}-1, \mathrm{NH}-1^{\prime}\right), 8.92(2 \mathrm{H}, \mathrm{t}, J=5.5 \mathrm{~Hz}, \mathrm{NH}-10$, NH$\left.10^{\prime}\right), 8.81$ (2H, d, $\left.J=3.3 \mathrm{~Hz}, \mathrm{H}-2, \mathrm{H}-2^{\prime}\right), 8.66-8.58$ (4H, m, NH $\mathrm{N}_{2}-14, \mathrm{NH}_{2}-14$ '), 8.20 (2H, d, $J=2.0 \mathrm{~Hz}, \mathrm{H}-4$, H-4'), 7.58 (2H, d, J=8.7 Hz, H-7, H-7'), 7.30 (2H, dd, $J=8.7,2.0$ Hz, H-6, H-6'), 3.33-3.28 (4H, m, H2-11, $\left.\mathrm{H}_{2}-11^{\prime}\right), 2.98-2.90$ (8H, m, H2-13, H $\left.\mathrm{H}_{2}-13^{\prime}, \mathrm{H}_{2}-15, \mathrm{H}_{2}-15^{\prime}\right), 1.90-1.82$ (4H, m, H2-12, H2-12'), 1.66-1.60 (4H, m, $\left.\mathrm{H}_{2}-16, \mathrm{H}_{2}-16^{\prime}\right) ;{ }^{13} \mathrm{C}$ NMR (100 MHz, DMSO- $\left.d_{6}\right) \delta 181.7$ (C-8, C-8'), 163.4 (C-9, C-9'), 139.7 (C-2, C-2'), 134.8 (C-7a, C-7a'), 127.5 (C-3a, C-3a'/C-5, C-5'), 127.3 (C-3a, C-3a'/C-5, C-5'), 123.5 (C-6, C-6'), 120.3 (C4, C-4'), 114.3 (C-7, C-7'), 111.7 (C-3, C-3'), 46.1 (C-15, C-15'), 44.7 (C-13, C-13'), 35.9 (C-11, C-11'), 25.7 (C-12, C-12'), 22.7 (C-16, C-16'); (+)-HRESIMS [M+Na] $]^{+} \mathrm{m} / z 635.1902$ (calcd for $\mathrm{C}_{30} \mathrm{H}_{34}{ }^{35} \mathrm{Cl}_{2} \mathrm{~N}_{6} \mathrm{O}_{4} \mathrm{Na}$, 635.1911), 637.1887 (calcd for $\mathrm{C}_{30} \mathrm{H}_{34}{ }^{35} \mathrm{Cl}^{37} \mathrm{ClN}_{6} \mathrm{O}_{4} \mathrm{Na}, 637.1890$ ), 639.1852 (calcd for $\mathrm{C}_{30} \mathrm{H}_{34}{ }^{37} \mathrm{Cl}_{2} \mathrm{~N}_{6} \mathrm{O}_{4} \mathrm{Na}$, 639.1877).

\subsubsection{7. $N^{l}, N^{4}$-Bis(3-(2-(6-chloro-1H-indol-3-yl)-2-oxoacetamido) propyl)butane-1,4-diaminium 2,2,2-} trifluoroacetate (10)

Using general procedure A, reaction of 6-chloro- $1 H$-indole (303 $\mathrm{mg}, 2 \mathrm{mmol}$ ) and oxalyl chloride $(0.195 \mathrm{~mL}, 2.3 \mathrm{mmol})$ afforded 2-(6-chloro-1H-indol-3-yl)-2-oxoacetyl chloride as a yellow powder. Using general procedure B, a sub-sample of the glyoxylyl chloride $(60 \mathrm{mg}, 0.248 \mathrm{mmol})$ was reacted with di-tertbutyl butane-1,4-diylbis((3-aminopropyl)carbamate) $(50 \mathrm{mg}, 0.124 \mathrm{mmol})$ and DIPEA $(0.130 \mathrm{~mL}, 0.744$ $\mathrm{mmol})$ in DMF $(2 \mathrm{~mL})$ to afford, after chromatography, di-tert-butyl butane-1,4-diylbis((3-(2-(6-chloro-1H- 
indol-3-yl)-2-oxoacetamido)propyl)carbamate) as a yellow oil (53 mg, 55\%). Using general procedure $\mathrm{C}$, a sub-sample of this material $(20 \mathrm{mg}, 0.025 \mathrm{mmol})$ was deprotected to afford the di-TFA salt of $\mathbf{1 0}$ as a brown oil (15 mg, 75\%). $\mathrm{R}_{\mathrm{f}}(\mathrm{MeOH} / 10 \% \mathrm{HCl}, 7: 3)$ 0.67; IR (ATR) $v_{\max } 3420,2254,1672,1632,1444,1179,1023$, $1002 \mathrm{~cm}^{-1} ;{ }^{1} \mathrm{H}$ NMR (DMSO- $\left.d_{6}, 400 \mathrm{MHz}\right) \delta 12.43$ (2H, br s, NH-1, NH-1'), 8.94 (2H, t, $J=6.1 \mathrm{~Hz}, \mathrm{NH}-10$, NH-10'), 8.80 (2H, d, $J=3.3$ Hz, H-2, H-2'), 8.59 (4H, m, NH$-14, \mathrm{NH}_{2}-14$ '), 8.20 (2H, d, J = 8.5 Hz, H-4, H4'), 7.61 (2H, d, $J=1.8 \mathrm{~Hz}, \mathrm{H}-7, \mathrm{H}-7$ ') 7.29 (2H, dd, $J=8.5,6.6 \mathrm{~Hz}, \mathrm{H}-5, \mathrm{H}-5$ '), 3.34-3.25 (4H, m, H ${ }_{2}-11, \mathrm{H}_{2}-$ 11'), 3.00-2.90 (8H, m, H2-13, H $\left.\mathrm{H}_{2}-13^{\prime}, \mathrm{H}_{2}-15, \mathrm{H}_{2}-15^{\prime}\right), 1.90-1.80$ (4H, m, H $\left.\mathrm{H}_{2}-12, \mathrm{H}_{2}-12^{\prime}\right), 1.66-1.57$ (4H, m, $\left.\mathrm{H}_{2}-16, \mathrm{H}_{2}-16^{\prime}\right) ;{ }^{13} \mathrm{C}$ NMR (DMSO- $\left.d_{6}, 100 \mathrm{MHz}\right) \delta 181.8$ (C-8, C-8'), 163.4 (C-9, C-9'), 158.4 (q, $J_{\mathrm{CF}}=36.1$ Hz, C-17, C-17'), 139.4 (C-2, C-2'), 136.8 (C-7a, C-7a'), 128.0 (C-6, C-6'), 125.0 (C-3a, C-3a'), 122.9 (C-4, C4'), 122.5 (C-5, C-5'), 112.5 (C-7, C-7'), 112.1 (C-3, C-3'), 46.1 (C-15, C-15'), 44.7 (C-13, C-13'), 35.8 (C-11, C-11'), 25.7 (C-12, C-12'), 22.7 (C-16, C-16'); (+)-HRESIMS [M+H] ${ }^{+} \mathrm{m} / z \quad 613.2070$ (calcd for $\mathrm{C}_{30} \mathrm{H}_{35}{ }^{35} \mathrm{Cl}_{2} \mathrm{~N}_{6} \mathrm{O}_{4}, 613.2091$ ), 615.2044 (calcd for $\mathrm{C}_{30} \mathrm{H}_{35}{ }^{35} \mathrm{Cl}^{37} \mathrm{ClN}_{6} \mathrm{O}_{4}, 615.2070$ ), 617.2023 (calcd for $\left.\mathrm{C}_{30} \mathrm{H}_{35}{ }^{37} \mathrm{Cl}_{2} \mathrm{~N}_{6} \mathrm{O}_{4}, 617.2058\right)$.

\subsubsection{8. $N^{l}, N^{4}$-Bis(3-(2-(7-chloro-1H-indol-3-yl)-2-oxoacetamido)propyl)butane-1,4-diaminium 2,2,2- trifluoroacetate (11)}

Using general procedure A, reaction of 7-chloro- $1 H$-indole (303 $\mathrm{mg}, 2 \mathrm{mmol}$ ) and oxalyl chloride $(0.195 \mathrm{~mL}, 2.3 \mathrm{mmol})$ afforded 2-(7-chloro- $1 H$-indol-3-yl)-2-oxoacetyl chloride as a yellow powder. Using general procedure $\mathrm{B}$, a sub-sample of the glyoxylyl chloride $(52 \mathrm{mg}, 0.248 \mathrm{mmol})$ was reacted with di-tertbutyl butane-1,4-diylbis((3-aminopropyl)carbamate) $(50 \mathrm{mg}, 0.124 \mathrm{mmol})$ and DIPEA $(0.130 \mathrm{~mL}, 0.744$ $\mathrm{mmol}$ ) in DMF (2 mL) to afford, after chromatography, di-tert-butyl butane-1,4-diylbis((3-(2-(7-chloro-1Hindol-3-yl)-2-oxoacetamido)propyl)carbamate) as a yellow oil (53 mg, 55\%). Using general procedure $\mathrm{C}$, a sub-sample of this material $(30 \mathrm{mg}, 0.037 \mathrm{mmol}$ ) was deprotected to afford the di-TFA salt of $\mathbf{1 1}$ as a brown oil (20 mg, 65\%). $\mathrm{R}_{\mathrm{f}}(\mathrm{MeOH} / 10 \% \mathrm{HCl}, 7: 3)$ 0.48; IR (ATR) $v_{\max } 2927,1674,1638,1505,1430,1203,1135$, 1026, 835, 799, $722 \mathrm{~cm}^{-1}$; ${ }^{1} \mathrm{H}$ NMR (400 MHz, DMSO- $\left.d_{6}\right) \delta 12.71\left(2 \mathrm{H}, \mathrm{d}, J=3.3 \mathrm{~Hz}, \mathrm{NH}-1, \mathrm{NH}-1^{\prime}\right), 8.95$ $\left(2 \mathrm{H}, \mathrm{t}, J=5.9 \mathrm{~Hz}, \mathrm{NH}-10, \mathrm{NH}-10^{\prime}\right), 8.77\left(2 \mathrm{H}, \mathrm{d}, J=3.3 \mathrm{~Hz}, \mathrm{H}-2, \mathrm{H}-2^{\prime}\right), 8.55-8.50$ (4H, m, NH${ }_{2}-14, \mathrm{NH}_{2}-$ 14'), 8.19 (2H, d, J=7.9 Hz, H-4, H-4'), 7.38 (2H, d, J=7.9 Hz, H-6, H-6'), 7.28 (2H, t, J= 7.9 Hz, H-5, H5'), 3.33-3.28 (4H, m, H $\left.\mathrm{H}_{2}-11, \mathrm{H}_{2}-11^{\prime}\right), 2.98-2.92$ (8H, m, H $\left.\mathrm{H}_{2}-13, \mathrm{H}_{2}-13^{\prime}, \mathrm{H}_{2}-15, \mathrm{H}_{2}-15^{\prime}\right), 1.90-1.83$ (4H, m, $\left.\mathrm{H}_{2}-12, \mathrm{H}_{2}-12^{\prime}\right), 1.65-1.57$ (4H, m, H $\left.\mathrm{H}_{2}-16, \mathrm{H}_{2}-16^{\prime}\right) ;{ }^{13} \mathrm{C}$ NMR (100 MHz, DMSO- $\left.d_{6}\right) \delta 181.8$ (C-8, C-8'), 163.3 (C-9, C-9'), 139.0 (C-2, C-2'), 133.2 (C-7a, C-7a'), 128.1 (C-3a, C-3a'), 123.8 (C-5, C-5'), 123.2 (C-6, C-6'), 120.2 (C-4, C-4'), 116.9 (C-7, C-7'), 112.9 (C-3, C-3'), 46.1 (C-15, C-15'), 44.7 (C-13, C-13'), 35.9 (C-11, C11'), 25.6 (C-12, C-12'), 22.7 (C-16, C-16'); (+)-HRESIMS [M+Na $]^{+} \mathrm{m} / z 635.1898$ (calcd for $\mathrm{C}_{30} \mathrm{H}_{34}{ }^{35} \mathrm{Cl}_{2} \mathrm{~N}_{6} \mathrm{O}_{4} \mathrm{Na}, 635.1911$ ), 637.1888 (calcd for $\mathrm{C}_{30} \mathrm{H}_{34}{ }^{35} \mathrm{Cl}^{37} \mathrm{ClN}_{6} \mathrm{O}_{4} \mathrm{Na}, 637.1890$ ), 639.1869 (calcd for $\left.\mathrm{C}_{30} \mathrm{H}_{34}{ }^{37} \mathrm{Cl}_{2} \mathrm{~N}_{6} \mathrm{O}_{4} \mathrm{Na}, 639.1877\right)$. 


\subsubsection{9. $N^{l}, N^{4}$-Bis(3-(2-(6-trifluoromethyl-1H-indol-3-yl)-2-oxoacet amido)propyl)butane-1,4-diaminium}

\section{2,2,2-trifluoroacetate (12)}

Using general procedure A, reaction of 6-trifluoromethyl- $1 H$-indole $(278 \mathrm{mg}, 1.5 \mathrm{mmol})$ and oxalyl chloride $(0.146 \mathrm{~mL}, 1.7 \mathrm{mmol})$ afforded 2-(6-trifluoromethyl- $1 H$-indol-3-yl)-2-oxoacetyl chloride as a yellow powder. Using general procedure $\mathrm{B}$, a sub-sample of the glyoxylyl chloride $(68 \mathrm{mg}, 0.248 \mathrm{mmol})$ was reacted with di-tert-butyl butane-1,4-diylbis((3-aminopropyl)carbamate) $(50 \mathrm{mg}, 0.124 \mathrm{mmol})$ and DIPEA $(0.130 \mathrm{~mL}$, $0.744 \mathrm{mmol})$ in DMF (2 mL) to afford, after chromatography, di-tert-butylbutane-1,4-diylbis((3-(2-oxo-2-(6(trifluoromethyl)-1 $H$-indol-3-yl)acetamido)propyl)carbamate) as a yellow oil (34 $\mathrm{mg}, 36 \%$ ). Using general procedure C, a sub-sample of this material $(24 \mathrm{mg}, 0.027 \mathrm{mmol})$ was deprotected to afford the di-TFA salt of 12 as a brown oil (14 mg, 58\%). $\mathrm{R}_{\mathrm{f}}(\mathrm{MeOH} / 10 \% \mathrm{HCl}, 7: 3)$ 0.48; IR (ATR) $v_{\max } 3017,2957,1671,1628,1494$, 1329, 1199, $1109 \mathrm{~cm}^{-1}$; ${ }^{1} \mathrm{H}$ NMR (DMSO- $\left.d_{6}, 400 \mathrm{MHz}\right) \delta 12.67$ (2H, br s, NH-1, NH-1'), 8.98-8.93 (4H, m, H-2, H-2', NH-10, NH-10'), 8.56 (4H, br s, $\mathrm{NH}_{2}-14, \mathrm{NH}_{2}-14$ '), 8.41 (2H, d, J=8.4 Hz, H-4, H-4'), 7.83 (2H, s, H-7, H-7'), 7.59 (2H, d, J=8.4 Hz, H-5, H-5'), 3.34-3.27 (4H, m, H2-11, H $\left.\mathrm{H}_{2}-11^{\prime}\right), 3.00-2.90$ (8H, m, H $\mathrm{H}_{2}-13$, $\left.\mathrm{H}_{2}-13^{\prime}, \mathrm{H}_{2}-15, \mathrm{H}_{2}-15^{\prime}\right), 1.90-1.80$ (4H, m, $\left.\mathrm{H}_{2}-12, \mathrm{H}_{2}-12^{\prime}\right)$, 1.67-1.57 (4H, m, $\mathrm{H}_{2}-16, \mathrm{H}_{2}-16$ '); ${ }^{13} \mathrm{C}$ NMR (DMSO$\left.d_{6}, 100 \mathrm{MHz}\right) \delta 182.0$ (C-8, C-8'), 163.3 (C-9, C-9'), 158.3 (q, ${ }^{2} J_{\mathrm{CF}}=35.0$ Hz, C-19, C-19'), 140.9 (C-2, C-2'), 135.4 (C-7a, C-7a'), 129.0 (C-3a, C-3a'), 124.1 (q, ${ }^{1} J_{\mathrm{CF}}=257.3 \mathrm{~Hz}, \mathrm{C}-17, \mathrm{C}-17$ '), 123.6 (q, ${ }^{2} J_{\mathrm{CF}}=31.7 \mathrm{~Hz}, \mathrm{C}-$ 6, C-6'), 122.0 (C-4, C-4'), 118.9 (C-5, C-5'), 112.1 (C-3, C-3'), 110.1 (C-7, C-7'), 46.1 (C-15, C-15'), 44.7 (C13, C-13'), 35.9 (C-11, C-11'), 25.7 (C-12, C-12'), 22.7 (C-16, C-16'); (+)-HRESIMS [M+H] $]^{+} \mathrm{m} / z$ 681.2625 (calcd for $\mathrm{C}_{32} \mathrm{H}_{35} \mathrm{~F}_{6} \mathrm{~N}_{6} \mathrm{O}_{4}, 681.2618$ ).

\subsubsection{0. $N^{l}, N^{4}$-Bis(3-(2-(5-cyano-1H-indol-3-yl)-2-oxoacetamido)propyl) butane-1,4-diaminium 2,2,2- trifluoroacetate (13)}

Using general procedure A, reaction of 5-cyano- $1 H$-indole $(142 \mathrm{mg}, 1 \mathrm{mmol})$ and oxalyl chloride $(0.097 \mathrm{~mL}, 1.15 \mathrm{mmol})$ afforded 2-(5-cyano-1H-indol-3-yl)-2-oxoacetyl chloride as a yellow powder. Using general procedure B, a sub-sample of the glyoxylyl chloride $(58 \mathrm{mg}, 0.248 \mathrm{mmol}$ ) was reacted with di-tertbutyl butane-1,4-diylbis((3-aminopropyl)carbamate) $(50 \mathrm{mg}, 0.124 \mathrm{mmol})$ and DIPEA $(0.130 \mathrm{~mL}, 0.744$ $\mathrm{mmol})$ in DMF $(2 \mathrm{~mL})$ to afford, after chromatography, di-tert-butyl butane-1,4-diylbis((3-(2-(5-cyano-1Hindol-3-yl)-2-oxoacetamido)propyl)carbamate) as a white gum (24 mg, 26\%). Using general procedure C, a sub-sample of this material ( $16 \mathrm{mg}, 0.020 \mathrm{mmol}$ ) was deprotected to afford the di-TFA salt of $\mathbf{1 3}$ as a brown oil (9.0 mg, 56\%). $\mathrm{R}_{\mathrm{f}}(\mathrm{MeOH} / 10 \% \mathrm{HCl}, 7: 3)$ 0.63; IR (ATR) $v_{\max }$ 3312, 2964, 2225, 1732 1668, 1448, 1209, 1126, $1037 \mathrm{~cm}^{-1} ;{ }^{1} \mathrm{H}$ NMR (DMSO- $\left.d_{6}, 400 \mathrm{MHz}\right) \delta 12.79\left(2 \mathrm{H}, \mathrm{d}, J=2.5 \mathrm{~Hz}, \mathrm{NH}-1, \mathrm{NH}-1^{\prime}\right), 8.98(2 \mathrm{H}, \mathrm{t}, J=$ 5.9 Hz, NH-10, NH-10'), 8.94 (2H, d, $J=2.5$ Hz, H-2, H-2'), 8.59-8.54 (6H, m, NH $\mathrm{N}_{2}-14, \mathrm{NH}_{2}-14$ ', H-4, H-4'), $7.75\left(2 \mathrm{H}, \mathrm{d}, J=8.5 \mathrm{~Hz}, \mathrm{H}-7, \mathrm{H}_{-} 7^{\prime}\right), 7.67$ (2H, dd, $J=8.5,1.5 \mathrm{~Hz}, \mathrm{H}-6, \mathrm{H}-6$ '), 3.34-3.25 (4H, m, H2-11, H 11'), 3.03-2.87 (8H, m, $\left.\mathrm{H}_{2}-13, \mathrm{H}_{2}-13^{\prime}, \mathrm{H}_{2}-15, \mathrm{H}_{2}-15^{\prime}\right), 1.92-1.80$ (4H, m, $\left.\mathrm{H}_{2}-12, \mathrm{H}_{2}-12^{\prime}\right), 1.68-1.58$ (4H, m, $\left.\mathrm{H}_{2}-16, \mathrm{H}_{2}-16^{\prime}\right) ;{ }^{13} \mathrm{C}$ NMR (DMSO- $\left.d_{6}, 100 \mathrm{MHz}\right) \delta 181.9$ (C-8, C-8'), 163.0 (C-9, C-9'), 158.5 (q, $J_{\mathrm{CF}}=34.0$ Hz, C-19, C-19'), 140.7 (C-2, C-2'), 138.2 (C-7a, C-7a'), 126.4 (C-6, C-6'), 126.05 (C-3a, C-3a'/C-4, C-4'), 
125.99 (C-3a, C-3a'/C-4, C-4'), 120.0 (C-17, C-17'), 114.2 (C-7, C-7'), 112.2 (C-3, C-3'), 104.8 (C-5, C-5'), 46.0 (C-15, C-15'), 44.7 (C-13, C-13'), 35.9 (C-11, C-11'), 25.6 (C-12, C-12'), 22.7 (C-16, C-16'); (+)HRESIMS $[\mathrm{M}+\mathrm{H}]^{+} m / z 595.2766$ (calcd for $\mathrm{C}_{32} \mathrm{H}_{35} \mathrm{~N}_{8} \mathrm{O}_{4}, 595.2776$ ).

\subsubsection{1. $N^{1}, N^{4}$-Bis(3-(2-(6-cyano-1H-indol-3-yl)-2-oxoacetamido)propyl) butane-1,4-diaminium 2,2,2- trifluoroacetate (14)}

Using general procedure A, reaction of 6-cyano- $1 H$-indole $(142 \mathrm{mg}, 1 \mathrm{mmol})$ and oxalyl chloride $(0.097 \mathrm{~mL}, 1.15 \mathrm{mmol})$ afforded 2-(6-cyano-1H-indol-3-yl)-2-oxoacetyl chloride as a yellow powder. Using general procedure B, a sub-sample of the glyoxyl chloride (58 $\mathrm{mg}, 0.248 \mathrm{mmol}$ ) was reacted with di-tert-butyl butane-1,4-diylbis((3-aminopropyl)carbamate) $(50 \mathrm{mg}, 0.124 \mathrm{mmol})$ and DIPEA $(0.130 \mathrm{~mL}, 0.744 \mathrm{mmol})$ in DMF (2 mL) to afford, after chromatography, di-tert-butyl butane-1,4-diylbis((3-(2-(6-cyano-1H-indol-3-yl)2-oxoacetamido)propyl)carbamate) as a white gum (43 mg, 45\%). Using general procedure $\mathrm{C}$, a sub-sample of this material (15 mg, $0.019 \mathrm{mmol})$ was deprotected to afford the di-TFA salt of $\mathbf{1 4}$ as a brown oil (10 mg, 66\%). $\mathrm{R}_{\mathrm{f}}(\mathrm{MeOH} / 10 \% \mathrm{HCl}, 7: 3)$ 0.57; IR (ATR) $v_{\max } 3040,2852,2223,1673,1635,1490,1200,1128,1024$ $\mathrm{cm}^{-1} ;{ }^{1} \mathrm{H}$ NMR (DMSO- $\left.d_{6}, 400 \mathrm{MHz}\right) \delta 12.81$ (2H, br s, NH-1, NH-1'), 9.00-8.93 (4H, m, H-2, H-2', NH-10, NH-10'), 8.64 (4H, br s, $\mathrm{NH}_{2}-14, \mathrm{NH}_{2}-14$ '), 8.36 (2H, d, $J=8.3$ Hz, H-4, H-4'), 8.07 (2H, br s, H-7, H-7'), 7.63 (2H, dd, $J=8.4,1.3$ Hz, H-5, H-5'), 3.34-3.27 (4H, m, H2-11, H $\left.\mathrm{H}_{2}-11^{\prime}\right), 3.00-2.90$ (8H, m, H $\mathrm{H}_{2}-13, \mathrm{H}_{2}-13^{\prime}, \mathrm{H}_{2}-$ 15, $\left.\mathrm{H}_{2}-15^{\prime}\right), 1.90-1.82\left(4 \mathrm{H}, \mathrm{m}, \mathrm{H}_{2}-12, \mathrm{H}_{2}-12 '\right), 1.65-1.56$ (4H, m, $\left.\mathrm{H}_{2}-16, \mathrm{H}_{2}-16{ }^{\prime}\right) ;{ }^{13} \mathrm{C}$ NMR (DMSO-d, 100 MHz) $\delta 181.9$ (C-8, C-8'), 163.2 (C-9, C-9'), 141.5 (C-2, C-2'), 135.3 (C-7a, C-7a'), 129.6 (C-3a, C-3a'), 125.5 (C-5, C-5'), 122.1 (C-4, C-4'), 119.7 (C-17, C-17'), 117.5 (C-7, C-7'), 112.2 (C-3, C-3'), 105.1 (C-6, C-6'), 46.1 (C-15, C-15'), 44.7 (C-13, C-13'), 35.9 (C-11, C-11'), 25.6 (C-12, C-12'), 22.7 (C-16, C-16'); (+)-HRESIMS $[\mathrm{M}+\mathrm{H}]^{+} m / z 595.2772$ (calcd for $\mathrm{C}_{32} \mathrm{H}_{35} \mathrm{~N}_{8} \mathrm{O}_{4}, 595.2776$ ).

\subsubsection{2. $N^{1}, N^{4}$-Bis(3-(2-(5-(methoxycarbonyl)-1H-indol-3-yl)-2-oxoacet amido)propyl)butane-1,4-}

\section{diaminium 2,2,2-trifluoroacetate (15)}

Using general procedure A, reaction of 5-methyl- $1 H$-indole carboxylate $(176 \mathrm{mg}, 1 \mathrm{mmol})$ and oxalyl chloride $(0.097 \mathrm{~mL}, 1.15 \mathrm{mmol})$ afforded methyl 3-(2-chloro-2-oxoacetyl)-1H-indole-5-carboxylate as a yellow powder. Using general procedure B, a sub-sample of the glyoxylyl chloride ( $77 \mathrm{mg}, 0.289 \mathrm{mmol}$ ) was reacted with di-tert-butyl butane-1,4-diylbis((3-aminopropyl)carbamate) (50 mg, $0.124 \mathrm{mmol})$ and DIPEA $(0.130 \mathrm{~mL}, 0.744 \mathrm{mmol})$ in DMF $(2 \mathrm{~mL})$ to afford, after chromatography, dimethyl 3,3'-(7,12-bis(tertbutoxycarbonyl)-2,17-dioxo-3,7,12,16-tetraazaoctadecanedioyl)bis( $1 \mathrm{H}$-indole-5-carboxylate) as a yellow oil (36 mg, 38\%). Using general procedure $\mathrm{C}$, this material (36 mg, $0.042 \mathrm{mmol}$ ) was deprotected to afford the di-TFA salt of 15 as a brown oil $(9.2 \mathrm{mg}, 25 \%)$. $\mathrm{R}_{\mathrm{f}}(\mathrm{MeOH} / 10 \% \mathrm{HCl}, 7: 3)$ 0.44; IR (ATR) $v_{\max } 3345,3040$, $1677,1619,1497,1433,1200,1111 \mathrm{~cm}^{-1} ;{ }^{1} \mathrm{H}$ NMR (DMSO- $\left.d_{6}, 400 \mathrm{MHz}\right) \delta 12.61$ (2H, s, NH-1, NH-1'), 8.958.89 (4H, m, H-4, H-4', NH-10, NH-10'), 8.87 (2H, d, $J=2.8$ Hz, H-2, H-2'), 8.56 (4H, br s, NH N-14, NH $_{2}$ 14'), 7.89 (2H, dd, $J=8.5,7.0$ Hz, H-6, H-6'), 7.65 (2H, d, $J=8.5$ Hz, H-7, H-7'), 3.88 (6H, s, $\left.\mathrm{H}_{3}-18, \mathrm{H}_{3}-18^{\prime}\right)$, 
3.36-3.28 (4H, m, $\left.\mathrm{H}_{2}-11, \mathrm{H}_{2}-11^{\prime}\right), 3.00-2.90$ ( $8 \mathrm{H}, \mathrm{m}, \mathrm{H}_{2}-13, \mathrm{H}_{2}-13$ ', $\left.\mathrm{H}_{2}-15, \mathrm{H}_{2}-15^{\prime}\right), 1.91-1.82$ (4H, m, $\mathrm{H}_{2}-12$, $\left.\mathrm{H}_{2}-12^{\prime}\right), 1.67-1.58$ (4H, m, $\left.\mathrm{H}_{2}-16, \mathrm{H}_{2}-16^{\prime}\right) ;{ }^{13} \mathrm{C}$ NMR (DMSO- $\left.d_{6}, 100 \mathrm{MHz}\right) \delta 182.0$ (C-8, C-8'), 166.8 (C-17, C-17'), 163.4 (C-9, C-9'), 140.2 (C-2, C-2'), 138.9 (C-7a, C-7a'), 125.8 (C-3a, C-3a'), 124.4 (C-6, C-6'), 123.9 (C-5, C-5'), 123.4 (C-4, C-4'), 112.8 (C-3, C-3', C-7, C-7'), 52.0 (C-18, C-18'), 46.1 (C-15, C-15'), 44.7 (C-13, C-13'), 35.9 (C-11, C-11'), 25.7 (C-12, C-12'), 22.7 (C-16, C-16'); (+)-HRESIMS [M+H] ${ }^{+} \mathrm{m} / z$ 661.2963 (calcd for $\left.\mathrm{C}_{34} \mathrm{H}_{41} \mathrm{~N}_{6} \mathrm{O}_{8}, 661.2980\right)$.

\subsubsection{3. $N^{1}, N^{4}$-Bis(3-(2-(6-(methoxycarbonyl)-1H-indol-3-yl)-2-oxoacet amido)propyl)butane-1,4-}

\section{diaminium 2,2,2-trifluoroacetate (16)}

Using general procedure A, reaction of 6-methyl- $1 H$-indole carboxylate $(176 \mathrm{mg}, 1 \mathrm{mmol})$ and oxalyl chloride $(0.097 \mathrm{~mL}, 1.15 \mathrm{mmol})$ afforded methyl 3-(2-chloro-2-oxoacetyl)-1H-indole-6-carboxylate as a yellow powder. Using general procedure B, a sub-sample of the glyoxylyl chloride ( $77 \mathrm{mg}, 0.289 \mathrm{mmol}$ ) was reacted with di-tert-butyl butane-1,4-diylbis((3-aminopropyl)carbamate) $(50 \mathrm{mg}, 0.124 \mathrm{mmol})$ and DIPEA $(0.130 \mathrm{~mL}, 0.744 \mathrm{mmol})$ in DMF $(2 \mathrm{~mL})$ to afford, after chromatography, dimethyl 3,3'-(7,12-bis(tertbutoxycarbonyl)-2,17-dioxo-3,7,12,16-tetraazaoctadecanedioyl)bis( $1 H$-indole-6-carboxylate) as a yellow oil (43 mg, 45\%). After a repeated synthesis, this material $(61 \mathrm{mg}, 0.071 \mathrm{mmol})$ was deprotected to afford the diTFA salt of 16 as a brown oil (59 mg, 97\%). $\mathrm{R}_{\mathrm{f}}(\mathrm{MeOH} / 10 \% \mathrm{HCl}, 9: 1)$ 0.87; IR (ATR) $v_{\max } 3314,2944,2261$, $1671,1621,1490,1284,1200,1133 \mathrm{~cm}^{-1} ;{ }^{1} \mathrm{H}$ NMR (DMSO- $\left.d_{6}, 400 \mathrm{MHz}\right) \delta 12.65(2 \mathrm{H}, \mathrm{d}, J=2.7 \mathrm{~Hz}, \mathrm{NH}-1$, NH-1'), 8.98-8.90 (4H, m, H-2, H-2', NH-10, NH-10'), 8.62 (4H, br s, $\left.\mathrm{NH}_{2}-14, \mathrm{NH}_{2}-14^{\prime}\right), 8.31$ (2H, d, $J=8.3$ Hz, H-4, H-4'), 8.18 (2H, d, J=1.1 Hz, H-7, H-7'), 7.87 (2H, dd, J=8.4, 7.0 Hz, H-5, H-5'), 3.88 (6H, s, H18, $\left.\mathrm{H}_{3}-18^{\prime}\right), 3.34-3.27$ (4H, m, $\left.\mathrm{H}_{2}-11, \mathrm{H}_{2}-11^{\prime}\right), 3.00-2.90$ (8H, m, $\mathrm{H}_{2}-13, \mathrm{H}_{2}-13$ ', $\left.\mathrm{H}_{2}-15, \mathrm{H}_{2}-15^{\prime}\right), 1.92-1.82$ $\left(4 \mathrm{H}, \mathrm{m}, \mathrm{H}_{2}-12, \mathrm{H}_{2}-12^{\prime}\right), 1.67-1.58\left(4 \mathrm{H}, \mathrm{m}, \mathrm{H}_{2}-16, \mathrm{H}_{2}-16^{\prime}\right) ;{ }^{13} \mathrm{C}$ NMR (DMSO-d, $\left.100 \mathrm{MHz}\right) \delta 181.9$ (C-8, C8'), 166.6 (C-17, C-17'), 163.4 (C-9, C-9'), 141.1 (C-2, C-2'), 135.7 (C-7a, C-7a'), 129.9 (C-3a, C-3a'), 124.5 (C-6, C-6'), 123.2 (C-5, C-5'), 121.0 (C-4, C-4'), 114.3 (C-7, C-7'), 112.2 (C-3, C-3'), 52.0 (C-18, C-18'), 46.0 (C-15, C-15'), 44.7 (C-13, C-13'), 35.8 (C-11, C-11'), 25.6 (C-12, C-12'), 22.7 (C-16, C-16'); (+)-HRESIMS $[\mathrm{M}+\mathrm{H}]^{+} \mathrm{m} / z 661.2959$ (calcd for $\mathrm{C}_{34} \mathrm{H}_{41} \mathrm{~N}_{6} \mathrm{O}_{8}, 661.2980$ ).

\subsubsection{4. $N^{1}, N^{4}$-Bis(3-(2-(7-(methoxycarbonyl)-1H-indol-3-yl)-2-oxoacet amido)propyl)butane-1,4-} diaminium 2,2,2-trifluoroacetate (17)

Using general procedure A, reaction of 7-methyl- $1 H$-indole carboxylate $(176 \mathrm{mg}, 1 \mathrm{mmol})$ and oxalyl chloride $(0.097 \mathrm{~mL}, 1.15 \mathrm{mmol})$ afforded methyl 3-(2-chloro-2-oxoacetyl)-1H-indole-7-carboxylate as a yellow powder. Using general procedure B, a sub-sample of the glyoxylyl chloride ( $77 \mathrm{mg}, 0.289 \mathrm{mmol}$ ) was reacted with di-tert-butyl butane-1,4-diylbis((3-aminopropyl)carbamate) $(50 \mathrm{mg}, 0.124 \mathrm{mmol})$ and DIPEA $(0.130 \mathrm{~mL}, 0.744 \mathrm{mmol})$ in DMF $(2 \mathrm{~mL})$ to afford, after chromatography, dimethyl 3,3'-(7,12-bis(tertbutoxycarbonyl)-2,17-dioxo-3,7,12,16-tetraazaoctadecanedioyl)bis(1H-indole-7-carboxylate) as a yellow oil (65 mg, 67\%). Using general procedure C, a sub-sample of this material (60 mg, $0.070 \mathrm{mmol})$ was deprotected 
to afford the di-TFA salt of $\mathbf{1 7}$ as a brown oil $(26 \mathrm{mg}, 43 \%)$. $\mathrm{R}_{\mathrm{f}}(\mathrm{MeOH} / 10 \% \mathrm{HCl}, 7: 3) 0.32$; IR (ATR) $v_{\max }$ $3321,2958,1670,1625,1505,1280,1202,1130 \mathrm{~cm}^{-1}$; ${ }^{1} \mathrm{H}$ NMR (DMSO- $\left.d_{6}, 400 \mathrm{MHz}\right) \delta 12.17$ (2H, s, NH-1, NH-1'), 8.96 (2H, t, $\left.J=6.0 \mathrm{~Hz}, \mathrm{NH}-10, \mathrm{NH}-10^{\prime}\right), 8.81$ (2H, d, $\left.J=3.2 \mathrm{~Hz}, \mathrm{H}-2, \mathrm{H}-2^{\prime}\right), 8.58$ (4H, br s, $\mathrm{NH}_{2}-14$, $\left.\mathrm{NH}_{2}-14 '\right), 8.54$ (2H, dd, $J=8.0,0.7 \mathrm{~Hz}, \mathrm{H}-4, \mathrm{H}-4$ '), 7.92 (2H, dd, $J=7.4,1.1 \mathrm{~Hz}, \mathrm{H}-6, \mathrm{H}-6$ '), 7.44-7.39 (2H, m, H-5, H-5'), 3.97 (6H, s, $\left.\mathrm{H}_{3}-18, \mathrm{H}_{3}-18^{\prime}\right)$, 3.34-3.27 (4H, m, H $\left.\mathrm{H}_{2}-11, \mathrm{H}_{2}-11^{\prime}\right)$, 3.00-2.90 (8H, m, H $\mathrm{H}_{2}-13, \mathrm{H}_{2}-13^{\prime}$,

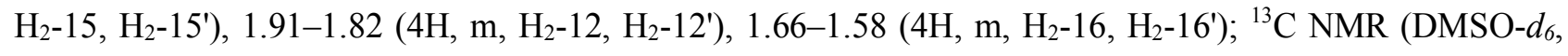
$100 \mathrm{MHz}) \delta 181.9$ (C-8, C-8'), 165.9 (C-17, C-17'), 163.2 (C-9, C-9'), 139.7 (C-2, C-2'), 134.4 (C-7a, C-7a'), 127.7 (C-3a, C-3a'), 126.9 (C-4, C-4'), 125.6 (C-6, C-6'), 122.5 (C-5, C-5'), 114.0 (C-7, C-7'), 112.0 (C-3, C3'), 52.2 (C-18, C-18'), 46.1 (C-15, C-15'), 44.7 (C-13, C-13'), 35.9 (C-11, C-11'), 25.6 (C-12, C-12'), 22.7 (C16, C-16'); (+)-HRESIMS [M+H] $]^{+} m / z 661.2961$ (calcd for $\mathrm{C}_{34} \mathrm{H}_{41} \mathrm{~N}_{6} \mathrm{O}_{8}, 661.2980$ ).

\subsubsection{5. $N^{1}, N^{4}$-Bis(3-(2-(5-methyl-1H-indol-3-yl)-2-oxoacetamido) propyl)butane-1,4-diaminium 2,2,2-} trifluoroacetate (18)

Using general procedure A, reaction of 5-methyl-1H-indole (262 mg, $2 \mathrm{mmol}$ ) and oxalyl chloride $(0.195 \mathrm{~mL}, 2.3 \mathrm{mmol})$ afforded 2-(5-methyl-1H-indol-3-yl)-2-oxoacetyl chloride as a yellow powder. Using general procedure B, a sub-sample of the glyoxylyl chloride $(55.2 \mathrm{mg}, 0.248 \mathrm{mmol})$ was reacted with di-tertbutyl butane-1,4-diylbis((3-aminopropyl)carbamate) $(50 \mathrm{mg}, 0.124 \mathrm{mmol})$ and DIPEA $(0.130 \mathrm{~mL}, 0.744$ mmol) in DMF (2 $\mathrm{mL})$ to afford di-tert-butyl butane-1,4-diylbis((3-(2-(5-methyl-1H-indol-3-yl)-2oxoacetamido)propyl)carbamate) as a white gum (40 mg, $42 \%$ ). Using general procedure $\mathrm{C}$, a sub-sample of this material (34 mg, $0.043 \mathrm{mmol}$ ) was deprotected to afford the di-TFA salt of $\mathbf{1 8}$ as a brown oil (34 mg, quant. yield). $\mathrm{R}_{\mathrm{f}}(\mathrm{MeOH} / 10 \% \mathrm{HCl}, 7: 3)$ 0.65; IR (ATR) $v_{\max } 3029,1672,1621,1428,1199,1129,1024,1004$ $\mathrm{cm}^{-1}$; ${ }^{1} \mathrm{H}$ NMR (DMSO- $\left.d_{6}, 400 \mathrm{MHz}\right) \delta 12.28\left(2 \mathrm{H}, \mathrm{br} \mathrm{s}, \mathrm{NH}-1, \mathrm{NH}-1^{\prime}\right), 8.87(2 \mathrm{H}, \mathrm{t}, J=6.1 \mathrm{~Hz}, \mathrm{NH}-10$, NH$\left.10^{\prime}\right), 8.70$ (2H, d, J=3.3 Hz, H-2, H-2'), 8.67 (4H, m, NH $2-14, \mathrm{NH}_{2}-14$ '), 8.04 (2H, s, H-4, H-4'), 7.42 (2H, d, $J=8.4$ Hz, H-7, H-7'), 7.09 (2H, dd, $J=8.3,7.2$ Hz, H-6, H-6'), 3.32-3.27 (4H, m, H2-11, H2-11'), 2.98-2.91 (8H, m, H2-13, H $\left.\mathrm{H}_{2}-13^{\prime}, \mathrm{H}_{2}-15, \mathrm{H}_{2}-15^{\prime}\right), 2.42$ (6H, s, H3-17, H3-17'), 1.90-1.83 (4H, m, H $\left.\mathrm{H}_{2}-12, \mathrm{H}_{2}-12^{\prime}\right), 1.65-$ $1.61\left(4 \mathrm{H}, \mathrm{m}, \mathrm{H}_{2}-16, \mathrm{H}_{2}-16^{\prime}\right) ;{ }^{13} \mathrm{C}$ NMR (DMSO- $\left.d_{6}, 100 \mathrm{MHz}\right) \delta 181.6$ (C-8, C-8'), 163.9 (C-9, C-9'), 158.6 (q, $\left.J_{\mathrm{CF}}=35.7 \mathrm{~Hz}, \mathrm{C}-19, \mathrm{C}-19^{\prime}\right), 138.4$ (C-2, C-2'), 134.6 (C-7a, C-7a'), 131.5 (C-5, C-5'), 126.5 (C-3a, C-3a'), 124.9 (C-6, C-6'), 121.0 (C-4, C-4'), 112.2 (C-7, C-7'), 111.8 (C-3, C-3'), 46.0 (C-15, C-15'), 44.7 (C-13, C13'), 35.8 (C-11, C-11'), 25.7 (C-12, C-12'), 22.7 (C-16, C-16'), 21.3 (C-17, C-17'); (+)-HRESIMS [M+H] ${ }^{+}$ $m / z 573.3174$ (calcd for $\mathrm{C}_{32} \mathrm{H}_{41} \mathrm{~N}_{6} \mathrm{O}_{4}, 573.3184$ ).

\subsubsection{6. $N^{1}, N^{4}$-Bis(3-(2-(7-methyl-1H-indol-3-yl)-2-oxoacetamido) propyl)butane-1,4-diaminium 2,2,2-} trifluoroacetate (19)

Using general procedure A, reaction of 7-methyl-1H-indole $(131 \mathrm{mg}, 1 \mathrm{mmol})$ and oxalyl chloride (0.097 mL, $1.15 \mathrm{mmol})$ afforded 2-(7-methyl-1H-indol-3-yl)-2-oxoacetyl chloride as a yellow powder. Using general procedure B, a sub-sample of the glyoxylyl chloride $(55.2 \mathrm{mg}, 0.248 \mathrm{mmol})$ was reacted with di-tert- 
butyl butane-1,4-diylbis((3-aminopropyl)carbamate) $(50 \mathrm{mg}, 0.124 \mathrm{mmol})$ and DIPEA $(0.130 \mathrm{~mL}, 0.744$ $\mathrm{mmol})$ in DMF $(2 \mathrm{~mL})$ to afford, after chromatography, di-tert-butyl butane-1,4-diylbis((3-(2-(7-methyl-1Hindol-3-yl)-2-oxoacetamido)propyl)carbamate) as a yellow oil (30 mg, 32\%). Using general procedure C, a sub-sample of this material $(18 \mathrm{mg}, 0.023 \mathrm{mmol})$ was deprotected to afford the di-TFA salt of $\mathbf{1 9}$ as a brown oil (12 mg, 65\%). $\mathrm{R}_{\mathrm{f}}(\mathrm{MeOH} / 10 \% \mathrm{HCl}, 7: 3)$ 0.40; IR (ATR) $v_{\max } 3052,1671,1619,1501,1445,1199,1126$, 1024, $1002 \mathrm{~cm}^{-1}$; ${ }^{1} \mathrm{H}$ NMR (DMSO- $\left.d_{6}, 400 \mathrm{MHz}\right) \delta 12.33$ (2H, br s, NH-1, NH-1'), 8.89 (2H, t, $J=5.7 \mathrm{~Hz}$, NH-10, NH-10'), 8.74 (2H, d, $J=3.0$ Hz, H-2, H-2'), 8.58-8.46 (4H, m, NH $2-14, \mathrm{NH}_{2}-14$ '), 8.06 (2H, d, $J=$ $7.8 \mathrm{~Hz}, \mathrm{H}-4, \mathrm{H}-4$ '), 7.16 (2H, t, $\left.J=7.5 \mathrm{~Hz}, \mathrm{H}-5, \mathrm{H}-5^{\prime}\right), 7.07$ (2H, d, J=7.2 Hz, H-6, H-6'), 3.34-3.26 (4H, m, $\left.\mathrm{H}_{2}-11, \mathrm{H}_{2}-11^{\prime}\right), 3.00-2.88$ (8H, m, H $\left.\mathrm{H}_{2}-13, \mathrm{H}_{2}-13^{\prime}, \mathrm{H}_{2}-15, \mathrm{H}_{2}-15^{\prime}\right), 2.51$ (6H, s, $\left.\mathrm{H}_{3}-17, \mathrm{H}_{3}-17^{\prime}\right), 1.90-1.81$ (4H, $\left.\mathrm{m}, \mathrm{H}_{2}-12, \mathrm{H}_{2}-12^{\prime}\right), 1.66-1.57$ (4H, m, H $\left.\mathrm{H}_{2}-16, \mathrm{H}_{2}-16^{\prime}\right) ;{ }^{13} \mathrm{C}$ NMR (DMSO-d $\left.6,100 \mathrm{MHz}\right) \delta 181.7$ (C-8, C-8'), 122.8 (C-5, C-5'), 121.9 (C-7, C-7'), 118.8 (C-4, C-4'), 112.5 (C-3, C-3'), 46.1 (C-15, C-15'), 44.7 (C-13, C13'), 35.8 (C-11, C-11'), 25.7 (C-12, C-12'), 22.7 (C-16, C-16'), 16.6 (C-17, C-17'); (+)-HRESIMS [M+H] ${ }^{+}$ $m / z 573.3170$ (calcd for $\mathrm{C}_{32} \mathrm{H}_{41} \mathrm{~N}_{6} \mathrm{O}_{4}, 573.3184$ ).

\subsubsection{N,N'-((Butane-1,4-diylbis(azanediyl))bis(propane-3,1-diyl))bis (2-(4-fluoro-1H-indol-3-yl)-2- oxoacetamide) (20)}

To a stirred solution of 2-(4-fluoro-1H-indol-3-yl)-2-oxoacetic acid [14] (38 mg, $0.18 \mathrm{mmol})$ and spermine (17 mg, $0.083 \mathrm{mmol})$ in DMF ( $1 \mathrm{~mL}$ ) was added PyBOP $\left(91 \mathrm{mg}, 0.18 \mathrm{mmol}\right.$ ) under $\mathrm{N}_{2}$ atmosphere. Triethylamine $(0.069 \mathrm{~mL}, 0.50 \mathrm{mmol})$ was then added and the reaction mixture was stirred for $48 \mathrm{~h}$. Solvent was removed under reduced pressure to afford a crude product that was triturated with $\mathrm{MeOH}: \mathrm{H}_{2} \mathrm{O}(1 \mathrm{~mL}, 1: 1)$ and the resulting solid was removed by filtration, washed and dried to afford $\mathbf{2 0}$ as the free base as a white powder (7.0 mg, 14\%). $\mathrm{R}_{\mathrm{f}}(\mathrm{MeOH} / 10 \% \mathrm{HCl}, 7: 3)$ 0.57; m.p $>250{ }^{\circ} \mathrm{C}$; IR (ATR) $v_{\max } 3274,2951,2742,1614$, 1501, 1427, 1312, $1258 \mathrm{~cm}^{-1} ;{ }^{1} \mathrm{H}$ NMR (DMSO- $\left.d_{6}, 400 \mathrm{MHz}\right) \delta 12.54$ (2H, br s, NH-1, NH-1'), 8.91 (2H, t, $J$ $\left.=5.9 \mathrm{~Hz}, \mathrm{NH}-10, \mathrm{NH}-10^{\prime}\right), 8.68$ (2H, s, H-2, H-2'), 7.37 (2H, d, J=8.0 Hz, H-7, H-7'), 7.26 (2H, td, J= 8.0, 4.7 Hz, H-6, H-6'), 6.97 (2H, dd, $J=11.0,7.9$ Hz, H-5, H-5'), 3.33-3.26 (4H, m, H2-11, H2-11'), 2.94-2.87 ( $\left.8 \mathrm{H}, \mathrm{m}, \mathrm{H}_{2}-13, \mathrm{H}_{2}-13^{\prime}, \mathrm{H}_{2}-15, \mathrm{H}_{2}-15^{\prime}\right), 1.93-1.84$ (4H, m, H2-12, H $\left.\mathrm{H}_{2}-12^{\prime}\right), 1.72-1.66$ (4H, m, H $\left.\mathrm{H}_{2}-16, \mathrm{H}_{2}-16^{\prime}\right)$; ${ }^{13} \mathrm{C}$ NMR (DMSO-d $\left.6,100 \mathrm{MHz}\right) \delta 181.0\left(\mathrm{C}-8, \mathrm{C}-8^{\prime}\right), 164.4$ (C-9, C-9'), 155.8 (d, $\left.{ }^{1} J_{\mathrm{CF}}=251.2 \mathrm{~Hz}, \mathrm{C}-4, \mathrm{C}-4{ }^{\prime}\right)$, $139.5\left(\mathrm{~d},{ }^{3} J_{\mathrm{CF}}=11.3 \mathrm{~Hz}, \mathrm{C}-7 \mathrm{a}, \mathrm{C}-7 \mathrm{a}^{\prime}\right), 138.9\left(\mathrm{C}-2, \mathrm{C}-2^{\prime}\right), 124.5\left(\mathrm{~d},{ }^{3} J_{\mathrm{CF}}=7.0 \mathrm{~Hz}, \mathrm{C}-6, \mathrm{C}-6\right.$ '), $113.4\left(\mathrm{~d},{ }^{2} J_{\mathrm{CF}}=\right.$ $\left.21.3 \mathrm{~Hz}, \mathrm{C}-3 \mathrm{a}, \mathrm{C}-3 \mathrm{a}^{\prime}\right), 111.8\left(\mathrm{~d},{ }^{3} J_{\mathrm{CF}}=6.1 \mathrm{~Hz}, \mathrm{C}-3, \mathrm{C}-3^{\prime}\right), 109.0\left(\mathrm{C}-7, \mathrm{C}-7^{\prime}\right), 108.0$ (d, ${ }^{2} J_{\mathrm{CF}}=21.7 \mathrm{~Hz}, \mathrm{C}-5, \mathrm{C}-$ 5'), 46.0 (C-15, C-15'), 44.7 (C-13, C-13'), 35.9 (C-11, C-11'), 25.7 (C-12, C-12'), 22.8 (C-16, C-16'); (+)HRESIMS $[\mathrm{M}+\mathrm{H}]^{+} m / z 581.2667$ (calcd for $\mathrm{C}_{30} \mathrm{H}_{35} \mathrm{~F}_{2} \mathrm{~N}_{6} \mathrm{O}_{4}, 581.2682$ ).

\subsection{Antimicrobial assays ${ }^{11,21}$}

The susceptibility of bacterial strains S. aureus (ATCC25923), S. intermedius (1051997), E. coli (ATCC25922) and P. aeruginosa (ATCC27853) to antibiotics and compounds was determined in microplates using the standard broth dilution method in accordance with the recommendations of the Comite de 
l'AntibioGramme de la Société Française de Microbiologie (CA-SFM). Briefly, the minimal inhibitory concentrations (MICs) were determined with an inoculum of $10^{5} \mathrm{CFU}$ in $200 \mu \mathrm{L}$ of Mueller-Hinton broth (MHB) containing two-fold serial dilutions of each drug. The MIC was defined as the lowest concentration of drug that completely inhibited visible growth after incubation for $18 \mathrm{~h}$ at $37^{\circ} \mathrm{C}$. To determine all MICs, the measurements were independently repeated in triplicate.

Additional antimicrobial evaluation against Klebsiella pneumoniae (ATCC700603), Acinetobacter baumannii (ATCC19606), Candida albicans (ATCC90028), and Cryptococcus neoformans (ATCC208821) was undertaken at the Community for Open Antimicrobial Drug Discovery at The University of Queensland (Australia) according to their standard protocols [21]. For antimicrobial assays, the tested strains were cultured in either Luria broth (LB) (In Vitro Technologies, USB75852), nutrient broth (NB) (Becton Dickson, 234000), or MHB at $37^{\circ} \mathrm{C}$ overnight. A sample of culture was then diluted 40-fold in fresh MHB and incubated at 37 ${ }^{\circ} \mathrm{C}$ for 1.5-2 h. The compounds were serially diluted 2-fold across the wells of 96-well plates (Corning 3641, nonbinding surface), with compound concentrations ranging from 0.015 to $64 \mu \mathrm{g} / \mathrm{mL}$, plated in duplicate. The resultant mid $\log$ phase cultures were diluted to the final concentration of $1 \times 10^{6} \mathrm{CFU} / \mathrm{mL}$; then, $50 \mu \mathrm{L}$ was added to each well of the compound containing plates giving a final compound concentration range of 0.008 to $32 \mu \mathrm{g} / \mathrm{mL}$ and a cell density of $5 \times 10^{5} \mathrm{CFU} / \mathrm{mL}$. All plates were then covered and incubated at $37^{\circ} \mathrm{C}$ for $18 \mathrm{~h}$. Resazurin was added at $0.001 \%$ final concentration to each well and incubated for $2 \mathrm{~h}$ before MICs were read by eye.

For the antifungal assay, fungi strains were cultured for 3 days on YPD agar at $30{ }^{\circ} \mathrm{C}$. A yeast suspension of $1 \times 10^{6}$ to $5 \times 10^{6} \mathrm{CFU} / \mathrm{mL}$ was prepared from five colonies. These stock suspensions were diluted with yeast nitrogen base (YNB) (Becton Dickinson, 233520) broth to a final concentration of $2.5 \times 10^{3}$ $\mathrm{CFU} / \mathrm{mL}$. The compounds were serially diluted 2-fold across the wells of 96-well plates (Corning 3641, nonbinding surface), with compound concentrations ranging from 0.015 to $64 \mu \mathrm{g} / \mathrm{mL}$ and final volumes of 50 $\mu \mathrm{L}$, plated in duplicate. Then, $50 \mu \mathrm{L}$ of the fungi suspension that was previously prepared in YNB broth to the final concentration of $2.5 \times 10^{3} \mathrm{CFU} / \mathrm{mL}$ was added to each well of the compound-containing plates, giving a final compound concentration range of 0.008 to $32 \mu \mathrm{g} / \mathrm{mL}$. Plates were covered and incubated at $35^{\circ} \mathrm{C}$ for 36 h without shaking. C. albicans MICs were determined by measuring the absorbance at $\mathrm{OD}_{530}$. For $C$. neoformans, resazurin was added at $0.006 \%$ final concentration to each well and incubated for a further $3 \mathrm{~h}$ before MICs were determined by measuring the absorbance at $\mathrm{OD}_{570-600}$.

Colistin and vancomycin were used as positive bacterial inhibitor standards for Gram-negative and Gram-positive bacteria, respectively. Fluconazole was used as a positive fungal inhibitor standard for $C$. albicans and C. neoformans. The antibiotics were provided in 4 concentrations, with 2 above and 2 below its MIC value, and plated into the first 8 wells of column 23 of the 384-well NBS plates. The quality control (QC) of the assays was determined by the antimicrobial controls and the $Z$ '-factor (using positive and negative controls). Each plate was deemed to fulfil the quality criteria (pass QC), if the Z'-factor was above 0.4, and the antimicrobial standards showed full range of activity, with full growth inhibition at their highest concentration, and no growth inhibition at their lowest concentration. 


\subsection{Determination of the MICs of antibiotics in the presence of synergizing compounds ${ }^{11}$}

Briefly, restoring enhancer concentrations were determined with an inoculum of $5 \times 10^{5} \mathrm{CFU}$ in 200 $\mu \mathrm{L}$ of MHB containing two-fold serial dilutions of each derivative in the presence of doxycycline at $2 \mu \mathrm{g} / \mathrm{mL}$. The lowest concentration of the polyamine adjuvant that completely inhibited visible growth after incubation for $18 \mathrm{~h}$ at $37^{\circ} \mathrm{C}$ was determined. These measurements were independently repeated in triplicate.

\subsection{Cytotoxicity assays ${ }^{21,22}$}

The L6 cell line cytotoxicity assays were performed in 96-well microtiter plates, each well containing $100 \mu \mathrm{L}$ of RPMI 1640 medium supplemented with $1 \%$ L-glutamine $(200 \mathrm{mM})$ and $10 \%$ fetal bovine serum, and $4 \times 10^{4}$ L6 cells (a primary cell line derived from rat skeletal myoblasts). Serial drug dilutions of seven 3fold dilution steps covering a range from 90 to $0.123 \mu \mathrm{g} / \mathrm{mL}$ were prepared. After $72 \mathrm{~h}$ of incubation, the plates were inspected under an inverted microscope to assure growth of the controls and sterile conditions. Alamar Blue solution $(10 \mu \mathrm{L})$ was then added to each well and the plates incubated for another $2 \mathrm{~h}$. Then the plates were read with a Spectramax Gemini XS microplate fluorometer using an excitation wavelength of $536 \mathrm{~nm}$ and an emission wavelength of $588 \mathrm{~nm}$. Data were analysed using the microplate reader software Softmax Pro. Podophyllotoxin was the reference drug used [22].

HEK293 cells were counted manually in a Neubauer haemocytometer and plated at a density of 5,000 cells/well into each well of the 384-well plates containing the $25 \mathrm{x}(2 \mu \mathrm{L})$ concentrated compounds. The medium used was Dulbecco's modified eagle medium (DMEM) supplemented with $10 \%$ fetal bovine serum (FBS). Cells were incubated together with the compounds for $20 \mathrm{~h}$ at $37^{\circ} \mathrm{C}, 5 \% \mathrm{CO}_{2}$. To measure cytotoxicity, $5 \mu \mathrm{L}$ (equals $100 \mu \mathrm{M}$ final) of resazurin was added to each well after incubation, and incubated for further $3 \mathrm{~h}$ at $37{ }^{\circ} \mathrm{C}$ with $5 \% \mathrm{CO}_{2}$. After final incubation fluorescence intensity was measured as Fex 560/10 nm, em $590 / 10 \mathrm{~nm}\left(\mathrm{~F}_{560 / 590}\right)$ using a Tecan M1000 Pro monochromator plate reader. $\mathrm{CC}_{50}$ values (concentration at 50\% cytotoxicity) were calculated by normalizing the fluorescence readout, with $74 \mu \mathrm{g} / \mathrm{mL}$ tamoxifen as negative control $(0 \%)$ and normal cell growth as positive control $(100 \%)$. The concentration-dependent percentage cytotoxicity was fitted to a dose response function (using Pipeline Pilot) and $\mathrm{CC}_{50}$ values determined.

\subsection{Haemolytic assay}

Haemolytic activities of the compounds were investigated by determining the hemoglobin release from erythrocyte suspensions of fresh Sprague Dawley (SD) rats blood. Fresh blood samples were obtained from the Vernon Jansen Unit (The University of Auckland) and stored in heparin-coated blood collection tubes. The blood cells were centrifuged at low speed for 5 mins and the plasma removed. The blood cells were then washed with saline (10 mL of saline for $1 \mathrm{~mL}$ of blood) and re-suspended in saline $2 \% \mathrm{v} / \mathrm{v}$. Re-suspended 
blood cells $(100 \mu \mathrm{L})$ were added to the compounds, dissolved in DMSO $(20 \mu \mathrm{L})$ and PBS buffer $(80 \mu \mathrm{L})$, in a 96-well plate and incubated for $1 \mathrm{~h}$ at $37^{\circ} \mathrm{C}$. After incubation the plate was centrifuged for $5 \mathrm{~min}$ at $200 \mathrm{~g}$, the supernatant $(100 \mu \mathrm{L})$ was transferred into another plate and the haemolysis was measured with a microplate reader at absorbance $540 \mathrm{~nm}$ (A). DMSO in PBS buffer was used as the negative control ( $0 \%$ haemolysis) while $0.1 \%$ Triton $\mathrm{X}-100$ was used as the positive control (100\% haemolysis). The percentage haemolysis was calculated as $\left(\mathrm{A}_{\text {compound }}-\mathrm{A}_{\text {negative control }}\right) /\left(\mathrm{A}_{\text {positive control}}-\mathrm{A}_{\text {negative control }}\right) \mathrm{x} 100$. All data corresponds to an average of three independent experiments. $\mathrm{HC}_{50}$ was determined from dose-response curves generated from 10 points in the 96-well plates.

\subsection{Measurement of ATP efflux ${ }^{11}$}

Squalamine solutions were prepared in doubly distilled water at different concentrations. A suspension of growing S. aureus or P. aeruginosa PAO1 to be studied in MHB was prepared and incubated at $37^{\circ} \mathrm{C} .90$ $\mu \mathrm{L}$ of this suspension was added to $10 \mu \mathrm{L}$ of squalamine solution and vortexed for $1 \mathrm{sec}$. Luciferin-luciferase reagent (Yelen, France; $50 \mu \mathrm{L}$ ) was immediately added to the precedent mix and luminescent signal quantified with an Infinite M200 microplate reader (Tecan) for five sec. ATP concentration was quantified by internal sample addition. A similar procedure was used for spermine $(100 \mu \mathrm{g} / \mathrm{mL}), 4$ and 8 (4 times the MIC).

\subsection{Membrane depolarization assays ${ }^{11}$}

Bacteria were grown in MHB for $24 \mathrm{~h}$ at $37^{\circ} \mathrm{C}$ and centrifuged at $10,000 \mathrm{rpm}$ at $20^{\circ} \mathrm{C}$. The supernatant was discarded, and the bacteria were washed twice with buffered sucrose solution $(250 \mathrm{mM})$ and magnesium sulfate solution $(5 \mathrm{mM})$. The fluorescent dye 3,3'-diethylthiacarbocyanine iodide was added to a final concentration of $3 \mu \mathrm{M}$, and it was allowed to penetrate into bacterial membranes during $1 \mathrm{~h}$ of incubation at $37^{\circ} \mathrm{C}$. Bacteria were then washed to remove the unbound dye before adding compound $\mathbf{4}$ or 8 at different concentrations. Fluorescence measurements were performed using a Jobin Yvon Fluoromax 3 spectrofluorometer with slit widths of $5 / 5 \mathrm{~nm}$. The maximum fluorescence was recorded with a pure solution of the fluorescent dye in buffer $(3 \mu \mathrm{M})$.

\subsection{Nitrocefin hydrolysis assay ${ }^{11}$}

Outer membrane permeabilization was measured using nitrocefin as a chromogenic substrate of periplasmic $\beta$-lactamase. Ten milliliters of MHB were inoculated with $0.1 \mathrm{~mL}$ of an overnight culture of EA289 bacteria and grown at $37^{\circ} \mathrm{C}$ until the $\mathrm{OD}_{600}$ reached 0.5 . The remaining steps were performed at room temperature. Cells were recovered by centrifugation (4,000 rpm for $20 \mathrm{~min}$ ) and washed once in $20 \mathrm{mM}$ potassium phosphate buffer ( $\mathrm{pH}$ 7.2) containing $\mathrm{MgCl}_{2}$ (1 mM). After a second centrifugation, the pellet was re-suspended and adjusted to $\mathrm{OD}_{600}$ of 0.5 . Then, $50 \mu \mathrm{L}$ of the desired compound were added to $100 \mu \mathrm{L}$ of the 
cell suspension to obtain a final concentration varying from $3.9 \mu \mathrm{M}$ to $250 \mu \mathrm{M}$. Fifty microliters of nitrocefin were then added to obtain a final concentration of $50 \mu \mathrm{g} / \mathrm{mL}$. Nitrocefin hydrolysis was monitored spectrophotometrically by measuring the increase in absorbance at $490 \mathrm{~nm}$. Assays were performed in 96 -well plates using a M200 Pro Tecan spectrophotometer.

\section{Acknowledgements}

We acknowledge funding from the Auckland Medical Research Foundation (1116001). We thank Dr. Michael Schmitz and Tony Chen for their assistance with the NMR and mass spectrometric data. Some of the antimicrobial screening was performed by CO-ADD (The Community for Antimicrobial Drug Discovery), funded by the Wellcome Trust (UK) and The University of Queensland (Australia). We thank Marcel Kaiser (Swiss Tropical Public Health Institute) for the L6 cytotoxicity data.

\section{Supplementary information}

Supplementary data related to this article can be found online at

\section{References}

[1] M. Hay, D.W. Thomas, J.L. Craighead, C. Economides, J. Rosenthal, Clinical development success rates for investigational drugs, Nat. Biotechnol. 32 (2014) 40-51. doi:10.1038/nbt.2786.

[2] S.B. Singh, Confronting the challenges of discovery of novel antibacterial agents, Bioorg. Med. Chem. Let. 24 (2014) 3683-3689. doi:10.1016/j.bmcl.2014.06.053

[3] L.L. Silver, Challenges of antibacterial discovery, Clin. Microbiol. Rev. 24 (2011) 71-109. doi:10.1128/CMR.00030-10

[4] S. Wagner, R. Sommer, S. Hinsberger, C. Lu, R.W. Hartmann, M. Empting, A. Titz, Novel strategies for the treatment of Pseudomonas aeruginosa infections, J. Med. Chem. 59 (2016) 5929-5969. doi: 10.1021/acs.jmedchem.5b01698

[5] K. Bush, Investigational agents for the treatment of Gram-negative bacterial infections: A reality check, ACS Infect. Dis. 1 (2015) 509-511. doi: 10.1021/acsinfecdis.5b00100

[6] L. Ejim, M.A. Farha, S.B. Falconer, J. Wildenhain, B.K Coombes, M. Tyers, E.D. Brown, G.D. Wright, Combinations of antibiotics and nonantibiotic drugs enhance antimicrobial efficacy, Nat. Chem. Biol. 7 (2011) 348-350. doi: 10.1038/NChemBio.559

[7] MA Farha, E.D. Brown, Discovery of antibiotic adjuvants, Nat. Biotechnol. 31 (2013) 120-122. doi: $10.1038 /$ nbt.2500. 
[8] C. González-Bello, Antibiotic adjuvants - A strategy to unlock bacterial resistance to antibiotics, Bioorg. Med. Chem. Lett. 27 (2017) 4221-4228. doi:10.1016/j.bmcl.2017.08.027

[9] R.J. Melander, C. Melander, The challenge of overcoming antibiotic resistance: an adjuvant approach? ACS Infect. Dis. 3 (2017) 559-563. doi: 10.1021/acsinfecdis.7b00071

[10] H. Douafer, V. Andrieu, O. Phanstiel, J.M. Brunel, Antibiotic adjuvants: make antibiotics great again! J. Med. Chem. ASAP. doi: 10.1021/acs.jmedchem.8b01781

[11] C. Pieri, D. Borselli, C. Di Giorgio, M. De Méo, J.-M. Bolla, N. Vidal, S. Combes, J.M. Brunel, New ianthelliformisamine derivatives as antibiotic enhancers against resistant Gram-negative bacteria, J. Med. Chem. 57 (2014) 4263-272. doi:10.1021/jm500194e

[12] T.L. Harris, R.J. Worthington, C. Melander, Potent small-molecule suppression of oxacillin resistance in methicillin-resistant Staphylococcus aureus, Angew. Chem. Intl. Ed. 51 (2012) 11254-11257. doi: 10.1002/anie.201206911

[13] S.A. Li, M.M. Cadelis, K. Sue, M. Blanchet, N. Vidal, J.M. Brunel, M.-L. Bourguet-Kondracki, B.R. Copp, 6-Bromoindolglyoxylamido derivatives as antimicrobial agents and antibiotic enhancers, Bioorg. Med. Chem. 27 (2019) 2090-2099. doi:10.1016/j.bmc.2019.04.004

[14] N.A. Meanwell, O.B. Wallace, H. Fang, H. Wang, M. Deshpande, T. Wang, Z. Yin, Z. Zhang, B.C. Pearce, J. James, K. Yeung, Z. Qiu, J.J.K. Wright, Z. Yang, L. Zadjura, D.L. Tweedie, S. Yeola, F. Zhao, S. Ranadive, B.A. Robinson, Y.-F. Gong, H.-G.H. Wang, T.P. Spicer, W.S. Blair, P.-Y. Shi, R.J. Colonno, P.-f. Lin, Inhibitors of HIV-1 attachment. Part 2: An initial survey of indole substitution patterns, Bioorg. Med. Chem. Lett. 19 (2009) 1977-1981. doi:10.1016/j.bmcl.2009.02.040

[15] J. Wang, K. Kaiser, B.R. Copp, Investigation of indolglyoxamide and indolacetamide analogues of polyamines as antimalarial and antitrypanosomal agents, Mar. Drugs 12 (2014) 3138-3160. doi:10.3390/md12063138

[16] K. Alhanout, S. Malesinki, N. Vidal, V. Peyrot, J.M. Rolain, J.M. Brunel, New insights into the antibacterial mechanism of action of squalamine, J. Antimicrob. Chemother. 65 (2010) 1688-1693. doi:10.1093/jac/dkq213

[17] L. Amaral, A. Martins, G. Spengler, J. Molnar, Efflux pumps of Gram-negative bacteria: what they do, how they do it, with what and how to deal with them, Front. Phamacol. 4 (2013) 168. doi: 10.3389/fphar.2013.00168

[18] M.A. Webber, L.J.V. Piddock, The importance of efflux pumps in bacterial antibiotic resistance, J. Antimicrob. Chemother. 51 (2003) 9-11. doi:10.1093/jac/dkg050

[19] L.P.P Liew, A.N. Pearce, M. Kaiser, B.R. Copp, Synthesis and in vitro and in vivo evaluation of antimalarial polyamines, Eur. J. Med. Chem. 69 (2013), 22-31. doi:10.1016/j.ejmech.2013.07.055 
[20] C. Murcia, L. Coello, R. Fernández, M.J. Martín, F. Reyes, A. Francesch, S. Munt, C. Cuevas, Tanjungides A and B: new antitumoral bromoindole derived compounds from Diazona cf formosa. Isolation and total synthesis, Mar. Drugs 12 (2014) 1116-1130. doi:10.3390/md12021116

[21] M.A. Blaskovich, J. Zuegg, A.G. Elliott, M.A. Cooper, Helping chemists discover new antibiotics. ACS Infect Dis. 1 (2015) 285-287. doi:10.1021/acsinfecdis.5b00044.

[22] I. Orhan, B. Şener, M. Kaiser, R. Brun, D. Tasdemir, Inhibitory activity of marine sponge derived natural products against parasitic protozoa, Mar Drugs 8 (2010) 47-58. doi:10.3390/md8010047. 